\title{
Modulation of genomic and epigenetic end-points by celecoxib
}

\author{
Alberto Izzotti ${ }^{1,2}$, Sebastiano La Maestra ${ }^{1}$, Rosanna T. Micale ${ }^{1}$, Alessandra Pulliero ${ }^{1}$, \\ Marta Geretto ${ }^{1}$, Roumen Balansky ${ }^{1,3}$ and Silvio De Flora ${ }^{1}$ \\ ${ }^{1}$ Department of Health Sciences, University of Genoa, 16132 Genoa, Italy \\ ${ }^{2}$ IRCCS Ospedale Policlinico San Martino, 16132 Genoa, Italy \\ ${ }^{3}$ National Center of Oncology, 1756 Sofia, Bulgaria \\ Correspondence to: Silvio De Flora, email: sdf@unige.it \\ Keywords: celecoxib; cigarette smoke; mouse models; DNA damage; microRNAs \\ Received: July 13,2018 Accepted: August 16, $2018 \quad$ Published: September 14, 2018 \\ Copyright: Izzotti et al. This is an open-access article distributed under the terms of the Creative Commons Attribution License 3.0 \\ (CC BY 3.0), which permits unrestricted use, distribution, and reproduction in any medium, provided the original author and source \\ are credited.
}

\section{ABSTRACT}

Celecoxib, a nonsteroidal anti-inflammatory drug that selectively targets cyclooxygenase-2, is a promising cancer chemopreventive agent. However, safety concerns have been raised in clinical trials evaluating its ability to prevent colorectal adenomas. The rationale for the herein reported studies was to analyze genomic and epigenetic end-points aimed at investigating both the chemopreventive properties of celecoxib towards cigarette smoke-associated molecular alterations and its possible adverse effects. We carried out three consecutive studies in mice treated with either smoke and/or celecoxib. Study 1 investigated early DNA alterations (DNA adducts, oxidative DNA damage, and systemic genotoxic damage) and epigenetic alterations (expression of 1,135 microRNAs) in lung and blood of Swiss H mice; Study 2 evaluated the formation of DNA adducts in lung, liver, and heart; and Study 3 evaluated the expression of microRNAs in 10 organs and 3 body fluids of ICR (CD-1) mice. Surprisingly, the oral administration of celecoxib to smoke-free mice resulted in the formation of DNA adducts in both lung and heart and in dysregulation of microRNAs in mouse organs and body fluids. On the other hand, celecoxib attenuated smokerelated DNA damage and dysregulation of microRNA expression. In conclusion, celecoxib showed pleiotropic properties and multiple mechanisms by counteracting the molecular damage produced by smoke in a variety of organs and body fluids. However, administration of celecoxib to non-smoking mice resulted in evident molecular alterations, also including DNA and RNA alterations in the heart, which may bear relevance in the pathogenesis of the cardiovascular adverse effects of this drug.

\section{INTRODUCTION}

Nonsteroidal anti-inflammatory drugs (NSAIDs) are extensively used worldwide for the treatment of inflammation-related diseases. Among other applications, these agents provide a promising approach to the prevention of cancer, also including smoking-associated cancers [1]. The rationale for such a strategy is that chronic inflammation plays a key role at different stages of the carcinogenesis process $[2,3]$ and is crucial in tobacco smoke carcinogenesis [4]. NSAIDs interfere with the metabolism of arachidonic acid, a $\omega-6$ essential fatty acid that is the substrate for different enzyme systems, including cyclooxygenases (COX), lipoxygenases, and cytochromes P450. Of the two COX enzymes, COX-1 is the housekeeping isoform, and the prostaglandins derived from COX-1 are involved in the homeostatic maintenance of the gastric mucosa. In contrast, COX-2 is the inducible isoform, expressed in response to certain stimuli such as mitogens, cytokines and growth factors, which has a proinflammatory function [5].

Based on these mechanistic premises, selective COX-2 inhibitors, called coxibs, have been developed to improve gastrointestinal (GI) safety and tolerability. They 
include drugs such as celecoxib, rofecoxib, valdecoxib, etoricoxib, and lumiracoxib. In particular, celecoxib (4-[5-(4-methylphenyl)-3-(trifluoromethyl)-1H-pyrazol1-yl] benzene-1-sulfonamide, CAS 169590-42-5) was the first selective COX-2 inhibitor approved to treat patients with rheumatism and osteoarthritis. Upper GI complication rates in clinical trials have been reported to be significantly lower for celecoxib than for traditional nonselective NSAIDs [6-8]. While several coxibs have been withdrawn from the market due to safety concerns, and especially to cardiovascular adverse events $[9,10]$, celecoxib continues to be available for use in many countries [11]. This coxib is approved by the US Food and Drug Administration (FDA) (https://www.fda.gov/ ForConsumers/ConsumerUpdates/ucm240959.htm).

It has been shown that COX-2 downregulation inhibits colorectal carcinogenesis [10]. Moreover, based on reports that suggest an association between cigarette smoke (CS) and COX-2-associated risk to develop cancer, celecoxib is under scrutiny for its possible ability to prevent cancer and for antagonizing the carcinogenic properties of CS, the most important threat to human health. In humans, a case-control study showed that use of celecoxib and other coxibs reduces the lung cancer risk [12]. A trial of celecoxib in former smokers decreased the bronchial proliferation, evaluated by measuring the Ki-67 labeling index, and reduced lung nodules on computed tomography [13]. In mice, administration of celecoxib reduced oxidative stress-mediated alterations, due to its ability to boost the antioxidant defense system [14]. Coxibs and other NSAIDs are being tested in animal models of cancer chemoprevention [15]. Celecoxib reduced pulmonary inflammation but failed to affect lung tumorigenesis in mice treated with either 3-methylcholanthrene-butylated hydroxytoluene or urethane [16], while it prevented $N$ butyl- $N$-(4-hydroxybutyl) nitrosamine-induced bladder carcinomas in rats [17]. We showed that administration of celecoxib after weanling to Swiss $\mathrm{H}$ mice, which had been exposed to mainstream cigarette smoke (MCS) since birth and thereafter kept in filtered air for an additional 3.5 months, results in a variety of protective effects towards MCS-related carcinogenesis [18]. In particular, celecoxib significantly attenuated MCSinduced alterations of inflammatory nature, including pulmonary emphysema, alveolar epithelial hyperplasias and lung microadenomas as well as urinary tract hyperplastic lesions. Moreover, the drug attenuated the yield of lung adenomas and showed some involvement in lowering the progression to cancer in the lung. However, in the same study celecoxib showed some hepatotoxicity in MCS-exposed mice [18], which is consistent with the demonstration that mediators derived from $\mathrm{COX}-2$ have an important hepatoprotective function and accordingly the risk of drug-induced liver injury may be increased by COX-2 inhibition [19].
The herein reported studies aimed at investigating both the chemopreventive properties of celecoxib in MCSexposed mice and, at the same time, the possible adverse effects of this drug in smoke-free mice. To this purpose, we carried out three consecutive studies by using preclinical models that evaluated genomic and epigenetic endpoints. In particular, the first study, referred to as Study 1, investigated early genomic alterations related to treatment of mice early in life with MCS and/or celecoxib. DNA alterations were evaluated in terms of bulky DNA adducts and oxidative DNA damage in lung and of systemic genotoxic damage, and epigenetic alterations were evaluated in terms of expression of microRNAs (miRNAs) in both lung and blood. This is the same murine model that we have extensively used to demonstrate, in the medium term, the carcinogenicity of MCS [20] and its modulation by a variety of putative cancer chemopreventive agents [21], also including celecoxib itself [18]. One of the findings of that study was that, while inhibiting the formation of DNA adducts in MCS-exposed mice, celecoxib induces the evident formation of DNA adducts in the lung of smoke-free mice. In order to validate the results of this study, we carried out a second study (Study 2) that specifically evaluated the selective formation of DNA adducts in the lung, liver, and heart of mice as related to exposure to MCS and administration of celecoxib. The third study (Study 3) was a quite extensive experiment that evaluated the expression of 1,135 miRNAs in 10 organs as related to the oral administration of celecoxib to adult mice, either smoke-free or MCS-exposed. Three body fluids were also examined, because extracellular miRNAs could serve as molecular biomarkers for diagnostic purposes applicable to both prevention and therapy of human diseases. The epigenetic alterations produced by MCS in this model, in the absence of chemopreventive agents, have previously been reported [22].

\section{RESULTS}

\section{Study 1. Evaluation of genomic and epigenetic end-points in the lung and blood serum of newborn Swiss $\mathrm{H}$ mice as related to treatment with celecoxib and/or exposure to MCS}

\section{Survival and body weights}

All mice survived after 10 weeks. The body weights in sham-exposed mice at weanling (about 4 weeks) were $23.9 \pm 0.75 \mathrm{~g}$ in males and $18.7 \pm 0.87 \mathrm{~g}$ in females and grew progressively until the 10 th week of life up to 40.0 $\pm 0.74 \mathrm{~g}$ and $29.2 \pm 0.56 \mathrm{~g}$, respectively. From the $3 \mathrm{rd}$ week onwards exposure to MCS resulted in a slight but statistically significant loss of body weight, which after 10 weeks was $33.9 \pm 0.62 \mathrm{~g}$ in males $(P<0.001$ as compared to sham) and $27.3 \pm 0.58 \mathrm{~g}$ in females $(P<0.05)$. As compared with sham-exposed mice, administration of celecoxib did not significantly affect the body weight, 
which was $37.2 \pm 0.97 \mathrm{~g}$ in males and $27.8 \pm 0.80 \mathrm{~g}$ in females. Celecoxib did not change the slight body weight loss caused by MCS, which was $34.6 \pm 1.55 \mathrm{~g}$ in males and $26.7 \pm 0.56 \mathrm{~g}$ in females. These figures were significantly lower than those recorded in sham-exposed mice $(P<$ 0.05 in both genders).

\section{Bulky DNA adducts in the lung}

Figure 1 shows examples of ${ }^{32} \mathrm{P}$ autoradiographs obtained by testing a blank, a positive control (BPDE-dG), and the lung DNA from Swiss $\mathrm{H}$ mice, either untreated (sham-exposed) or exposed to MCS during the first 10 weeks of life, and either untreated or treated with oral celecoxib for 6 weeks after weanling. Exposure of mice to MCS caused the formation of a massive diagonal radioactive zone (DRZ), which is typical of exposures to complex mixtures. Administration of celecoxib to MCS-free mice resulted in the formation of 3 autoradiographic spots that were absent in sham-exposed mice. It is not possible to ascertain whether the same DNA adducts were also present in the lung of MCS-exposed mice treated with this drug because the autoradiographic spots may have been masked and overwhelmed by the MCS-induced DRZ.

Table 1 (left column) reports the levels of pulmonary bulky DNA adducts in the 4 experimental groups, each one
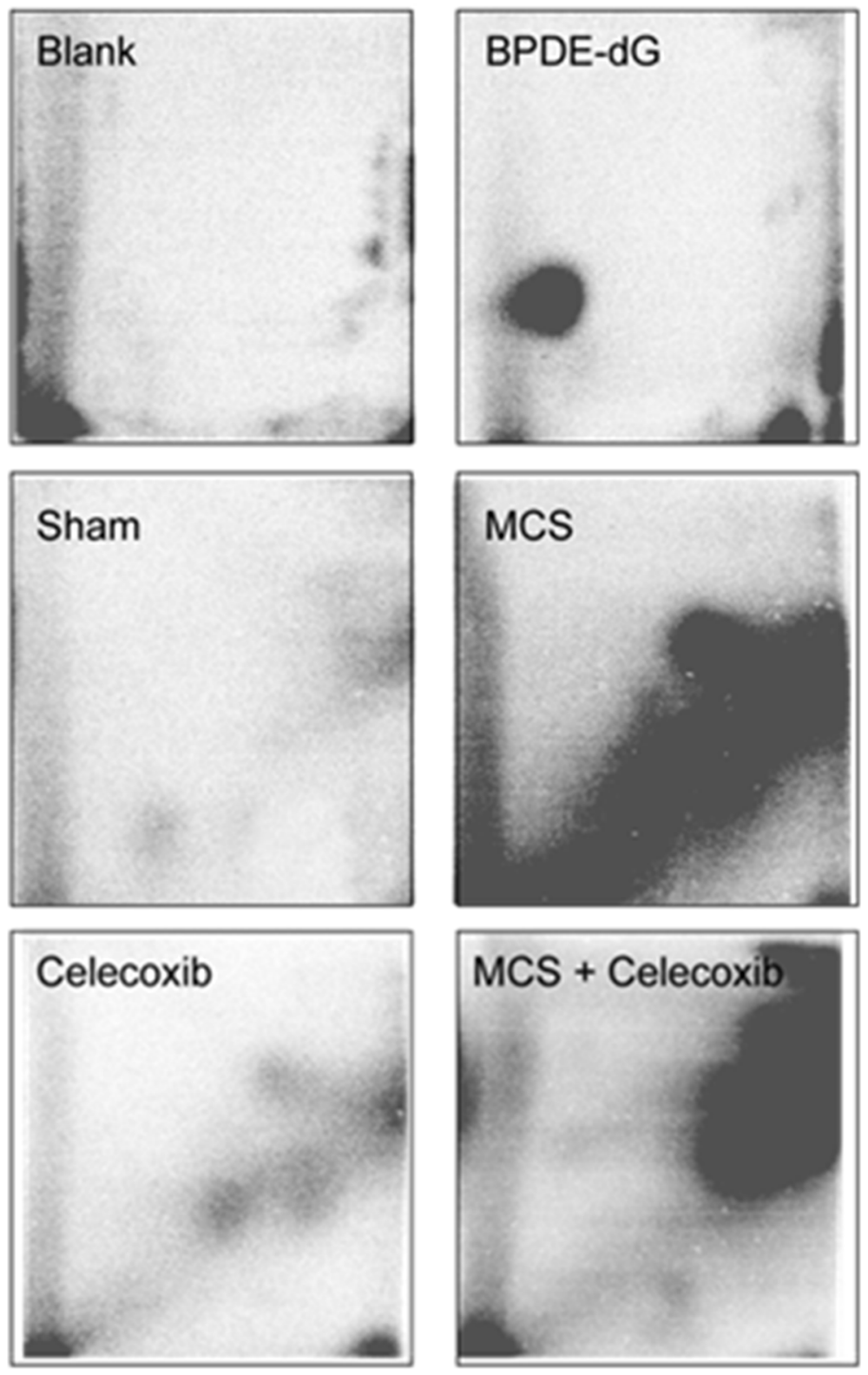

Figure 1: Examples of ${ }^{32} \mathrm{P}$ autoradiographs obtained by testing a blank, a positive control (BPDE-dG), and the lung DNA from Swiss H mice, either untreated (sham-exposed) or treated with celecoxib for 6 weeks after weanling or exposed to MCS for 10 weeks since birth or exposed to MCS and treated with celecoxib. 
Table 1: Bulky DNA adducts and 8-oxo-dGuo evaluated by ${ }^{32} \mathrm{P}$ postlabeling in the lungs of $40 \mathrm{Swiss} \mathrm{H}$ mice belonging to 4 experimental groups, as related to gender, exposure to MCS, and treatment with celecoxib

\begin{tabular}{|c|c|c|c|}
\hline Treatment & Gender & $\begin{array}{c}\text { Adducts/ } \\
10^{8} \text { nucleotides }\end{array}$ & $\begin{array}{c}\text { 8-oxo-dGuo/ } \\
10^{5} \text { nucleotides }\end{array}$ \\
\hline \multirow[t]{3}{*}{ Sham } & M & $1.3 \pm 0.19$ & $1.7 \pm 0.25$ \\
\hline & $\mathrm{F}$ & $1.2 \pm 0.17$ & $2.1 \pm 0.20$ \\
\hline & $\mathrm{M}+\mathrm{F}$ & $1.3 \pm 0.12$ & $1.9 \pm 0.17$ \\
\hline \multirow[t]{3}{*}{ Celecoxib } & M & $4.3 \pm 0.40^{\mathrm{b}}$ & $1.6 \pm 0.29$ \\
\hline & $\mathrm{F}$ & $4.3 \pm 0.34^{\mathrm{b}}$ & $2.3 \pm 0.28$ \\
\hline & $\mathrm{M}+\mathrm{F}$ & $4.3 \pm 0.25^{\mathrm{b}}$ & $1.9 \pm 0.22$ \\
\hline \multirow[t]{3}{*}{ MCS } & M & $17.9 \pm 1.77^{b}$ & $5.0 \pm 0.18^{b}$ \\
\hline & $\mathrm{F}$ & $20.0 \pm 3.30^{b}$ & $6.0 \pm 0.44^{b}$ \\
\hline & $\mathrm{M}+\mathrm{F}$ & $18.9 \pm 1.59^{b}$ & $5.5 \pm 0.26$ \\
\hline \multirow[t]{3}{*}{ MCS + Celecoxib } & M & $11.5 \pm 2.08^{\mathrm{b}, \mathrm{c}}$ & $2.2 \pm 0.27^{\mathrm{c}}$ \\
\hline & $\mathrm{F}$ & $9.8 \pm 1.91^{\mathrm{a}, \mathrm{c}}$ & $1.9 \pm 0.22^{\mathrm{c}}$ \\
\hline & $\mathrm{M}+\mathrm{F}$ & $11.0 \pm 0.30^{\mathrm{b}, \mathrm{c}}$ & $2.1 \pm 0.17^{\mathrm{c}}$ \\
\hline
\end{tabular}

The results are means \pm SE of the results obtained in the 5 mice composing each group.

Statistical analysis: ${ }^{\mathrm{a}} P<0.01$ and ${ }^{\mathrm{b}} P<0.001$, as compared with sham-exposed mice; ${ }^{\mathrm{c}} P<0.05$ and ${ }^{\mathrm{d}} P<0.001$, as compared with MCS-exposed mice.

composed of 5 males (M) and 5 females (F). There were no significant intergender differences within any groups. Treatment of mice with celecoxib caused a significant, 3.3-fold increase of DNA adducts, as compared with sham-exposed mice, which reflects the presence of the 3 celecoxib-specific autoradiographic spots shown in Figure 1. The autoradiographic DRZ detected by ${ }^{32} \mathrm{P}$ postlabeling in MCS-exposed mice corresponded to a 14.5-fold increase of pulmonary DNA adduct levels in combined genders. Administration of celecoxib to MCSexposed mice significantly decreased the formation of DNA adducts in parallel to an evident attenuation of the DRZ (see Figure 1). In any case, DNA adduct levels in this group were still significantly higher $(8.5$-fold) compared to sham-exposed mice.

\section{Oxidative DNA damage in the lung}

Table 1 (right column) reports the levels of pulmonary 8-oxo-dGuo in the DNA of the same 4 experimental groups of Swiss $\mathrm{H}$ mice used for measuring bulky DNA adducts. Again, there was no intergender differences within any group. Exposure of mice to MCS caused a significant oxidative DNA damage in the lung, as documented by a 2.9-fold, statistically significant increase of 8-oxo-dGuo levels. Administration of celecoxib to MCS-free mice did not affect 8-oxo-dGuo levels as compared with sham-exposed mice, whereas its administration to MCS-exposed mice significantly attenuated the oxidative DNA damage to such an extent that the 8-oxo-dGuo levels detected in MCS-exposed mice treated with celecoxib were undistinguishable from those detected in sham-exposed mice.

\section{Systemic MCS genotoxicity}

Modulation by celecoxib of the systemic genotoxicity was evaluated by measuring the frequency of MN NCE in the blood of mice exposed to MCS during the first 4 months of life, since birth, and/or treated with celecoxib after weanling until the 4th month of life. Exposure to MCS of both male and female mice resulted in significant increases in MN NCE frequency, as compared with sham-exposed mice $(1.9 \pm 0.14$ vs. 1.3 \pm 0.10 in males and $1.2 \pm 0.06$ vs. $0.8 \pm 0.08$ in females; $P<0.01$ in both cases). Administration of celecoxib had no significant effect on the frequency of MN NCE either in MCS-free mice $(1.4 \pm 0.12$ in males and $0.8 \pm 0.08$ in females) or in MCS-exposed mice $(2.2 \pm 0.15$ in males and $1.2 \pm 0.08$ in females).

\section{Modulation of pulmonary miRNAs}

miRNA expression profiles were analyzed in the Swiss $\mathrm{H}$ mice belonging to the same 4 experimental groups examined for DNA end-points. Overall comparisons are shown in Figure 2, which reports the results of HCA (A) and bidimensional PCA (B). According to the former approach, it appears that Sham and MCS are allocated far away in the dendrogram. Celecoxib is close to Sham, and 
MCS + celecoxib is linked to the MCS branch. Similarly, the Sham and MCS symbols fall in opposite quadrants at PCA. Celecoxib is in the quadrant nearby Sham, and MCS + Celecoxib is close to MCS.

Figure 3 shows SPAs comparing the intensity of expression of pulmonary miRNAs either in sham-exposed mice $v s$. mice receiving celecoxib (upper panel), or in mice exposed to MCS, in the absence of celecoxib, vs. MCS-exposed mice receiving celecoxib (bottom panel). The miRNAs falling outside the diagonal 2-fold were mainly located in the lower part of the diagram, which includes miRNAs expressed at low intensity levels. As inferred from volcano-plot analyses (not shown), the number of miRNAs changing their expression more than 2-fold and above the statistical significance threshold as compared with sham-exposed mice was $21(1.9 \%)$ in celecoxib-treated mice, of which 19 were upregulated and 2 were downregulated. The identity of these miRNAs and their main functions are reported in Table 2 (left column). The right column of the same table reports the miRNAs that were significantly dysregulated by celecoxib in MCSexposed mice. These included 11 miRNAs $(1.0 \%)$, all of them upregulated by celecoxib both in MCS-free and MCS-exposed mice.
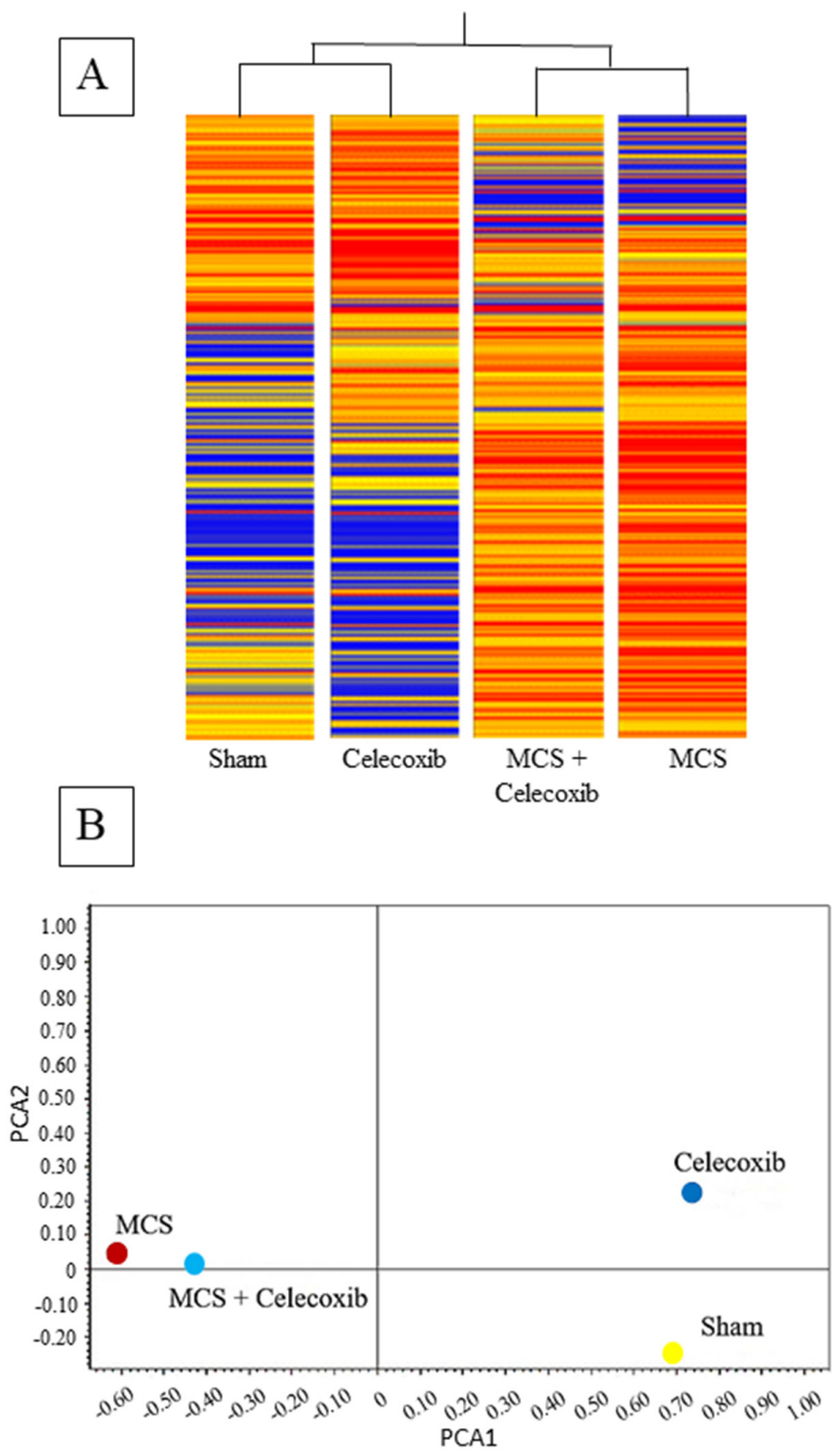

Figure 2: HCA (A) and bidimensional PCA (B) comparing the expression profiles of pulmonary miRNAs in sham-exposed mice and mice exposed to MCS during the first 10 weeks of life, either untreated or treated with celecoxib for 6 weeks after weanling. 


\section{Modulation of blood serum miRNAs}

The concentrations of miRNAs in blood serum were evaluated in the same Swiss $\mathrm{H}$ mice in which pulmonary miRNAs had been analyzed. The comparison of Figure $2 \mathrm{~A}$ and Figure $4 \mathrm{~A}$ shows at a glance that the concentrations of circulating miRNAs were much lower than those of pulmonary miRNAs, as inferred from the different color of the bands composing each column (blue, low intensity; red, high intensity). The distribution patterns of the experimental groups in the hierarchical tree
(Figure 4A) shows that Sham and MCS are far away in the dendrogram. Celecoxib and MCS + Celecoxib are close in the same branch, which is linked to the MCS branch. Allocation of symbols according to bidimensional PCA (Figure 4B) shows that MCS and Sham are located far away from each other, with the MCS + Celecoxib symbol half-way between Sham and MCS and the Celecoxib symbol allocated from the same side of Sham.

SPA compared miRNA levels in the blood serum of sham-exposed mice $v s$. either celecoxib-treated mice (Figure 5, upper panel) or MCS-exposed mice (Figure
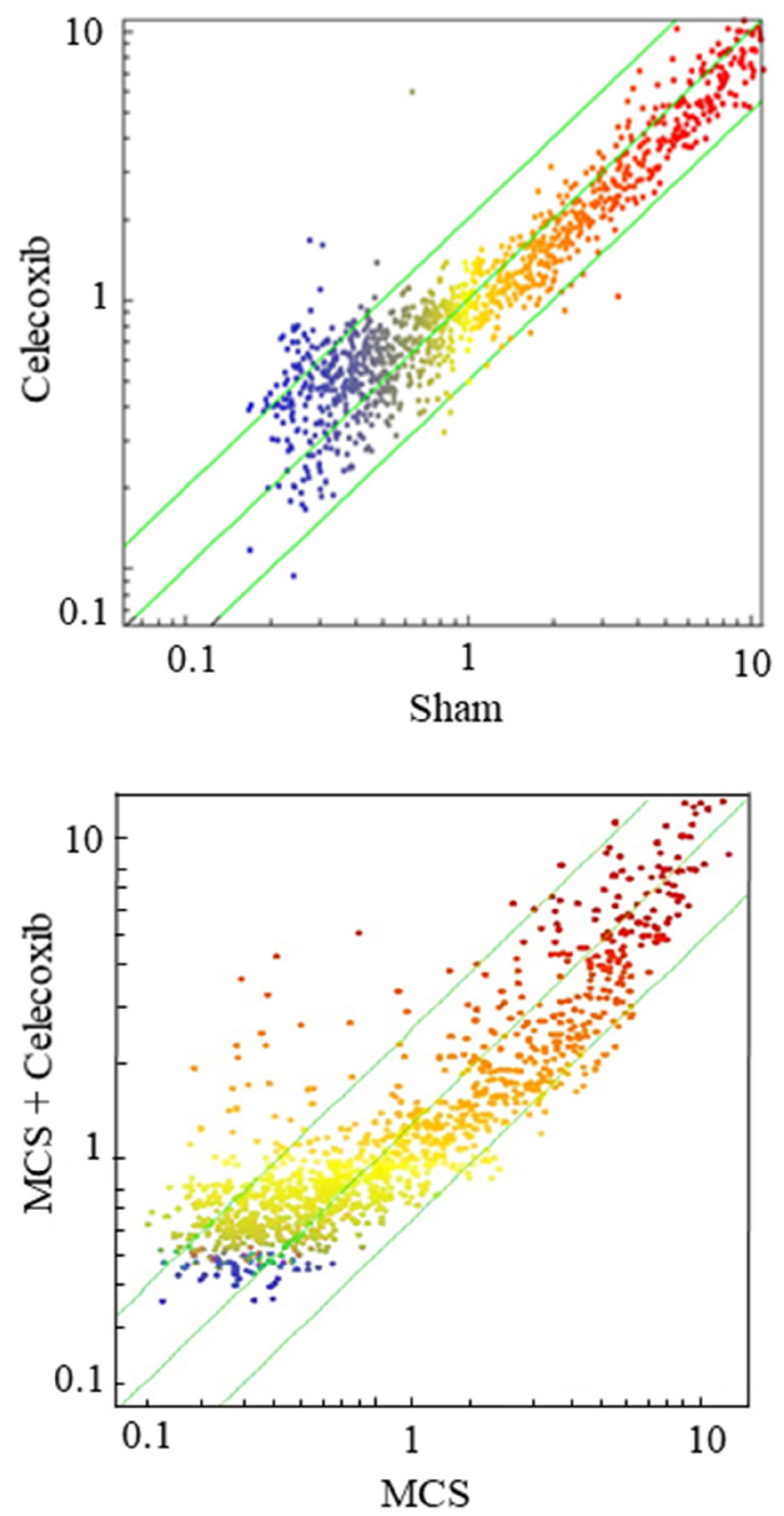

Figure 3: SPAs comparing the expression of 1,135 pulmonary miRNAs either in sham-exposed mice vs. mice receiving celecoxib with the diet for 6 weeks, starting after weanling (upper panel), or in mice exposed to MCS during the first 10 weeks of life, in the absence of celecoxib, vs. MCS-exposed mice receiving celecoxib (bottom panel). Each dot represents a miRNA, whose expression intensity can be inferred from the position in the $\mathrm{x}$ - and $\mathrm{y}$-axes according to a color scale (blue, low; yellow, medium; orange to red, high). The diagonal belts indicate the 2-fold variation intervals. Symbols falling in the upper left area denote miRNA upregulation by celecoxib, and those falling in the bottom right area denote miRNA downregulation by celecoxib. 
Table 2: List and functions of miRNAs, as inferred from volcano plot analyses, whose expression varied at least 2-fold and to a statistically significant extent in the lung of Swiss $\mathrm{H}$ mice as a result of celecoxib administration either to sham-exposed mice or to MCS-exposed mice

\begin{tabular}{lccc}
\hline miRNA & Celecoxib/Sham & MCS + Celecoxib/MCS & Function \\
\hline miR-106a & 3.27 & 2.49 & Cell adhesion, TNF activation, stress response \\
miR-181c & 2.13 & - & NFkB stress response \\
miR-193 & 2.77 & - & Signal transduction \\
miR-196b & 2.04 & - & TGF-beta \\
miR-208 & 2.22 & - & Heart damage \\
miR-290 & 2.21 & 2.82 & Stem cell marker \\
miR-381 & 2.66 & 2.15 & Cell proliferation \\
miR-471 & 2.97 & 2.42 & LC3-associated phagocytosis \\
miR-511 & 2.28 & - & Inflammation, monocyte activation \\
miR-582 & 3.36 & - & Cell proliferation, apoptosis \\
miR-615 & 2.37 & 2.92 & Macrophage activation \\
miR-701 & 2.54 & - & NA \\
miR-758 & 3.28 & 2.71 & Cell proliferation, apoptosis \\
miR-1193 & 0.41 & - & Cell proliferation, apoptosis \\
miR-1195 & 0.40 & - & MAP kinase signaling pathway, cytochrome CYP2s1 \\
miR-1247 & 2.30 & 2.03 & activity \\
miR-1251 & 2.83 & - & Fibroblasts activation, increase of pro-inflammatory \\
miR-3070 & 3.38 & 2.00 & gene expression \\
miR-3085 & 2.27 & 3.17 & Signal transduction by targeting IGF1 \\
miR-3109 & 2.04 & 2.58 & NA \\
miR-5617 & 2.13 & 4.17 & NA \\
\hline & & & NA \\
\hline
\end{tabular}

NA, not available.

5, middle panel) or MCS+celecoxib vs. MCS-exposed mice in the absence of chemopreventive agent (Figure 5, bottom panel). The concentration of several miRNAs was altered in the blood serum of celecoxib-treated mice as compared with sham-exposed mice. Identity, variations, and functions (as inferred from literature and Targetscan database) of the 18 miRNAs that were significantly modulated in blood serum by celecoxib, as compared with sham-exposed mice, are reported in Table 3 (left column). These miRNAs were identified by volcano-plot analysis (not shown) using 2 -fold variation and $P<0.05$ significance ANOVA thresholds. Two of these miRNAs (miR-181, miR-208a) were also upregulated by celecoxib in the lung tissue (see Table 2). In addition, the miRNAs altered by celecoxib in blood serum included many miRNAs that were not modulated by this drug in the lung. Seven of the 18 blood miRNAs altered by celecoxib are liver specific, thus their presence in blood reflects celecoxib-induced modifications occurring in this organ. It is of interest that miR-208a, which has been related to the occurrence of heart damage, was well detectable in blood serum following celecoxib administration.

MCS was much more effective than celecoxib in altering miRNA expression in blood serum. The SPA reported in Figure 5 (bottom panel) shows that multiple miRNAs fall outside the 2-fold variation interval in MCS-exposed mice as compared with sham-exposed mice. Few miRNAs, mainly expressed at low levels, are downregulated (bottom right area, blue color dots falling outside the 2 -fold variation interval). Conversely, the majority of MCS-altered miRNAs were upregulated and characterized by high level of expression (top left area, red dots falling outside the 2-fold variation interval). Identity, variations, and functions of the 30 
blood miRNAs that were significantly altered by MCS compared with sham-exposed mice, as identified by volcano-plot analysis (not shown), are reported in Table 3. MCS induced a prevalent upregulation of miRNAs. In fact, as many as 29 out of the 30 altered miRNAs were upregulated.

Celecoxib was effective in counteracting the effect of MCS on 7 blood miRNAs (Table 3). This finding reflects chemopreventive mechanisms activated by this drug in MCS target organs, mainly including the lung but also kidney and skin, as indicated by the tissue specificity of the modulated miRNAs (see Table 3, last column on the right).

\section{Study 2. Bulky DNA adducts in lung, liver, and heart of ICR (CD-1) mice exposed to MCS and/ or treated with celecoxib}

Figure 6 shows examples of ${ }^{32} \mathrm{P}$ autoradiographs obtained by testing the lung, liver, and heart DNA from ICR (CD-1) mice, as related to treatment with celecoxib and/ or exposure to MCS. Exposure of mice to MCS resulted in the formation of massive DRZs in both heart and lung, whereas in the liver such an effect was marginal. Treatment of smoke-free mice with celecoxib caused the formation of 3 autoradiographic spots in the lung, having a localization similar to the one observed in the previous study (see

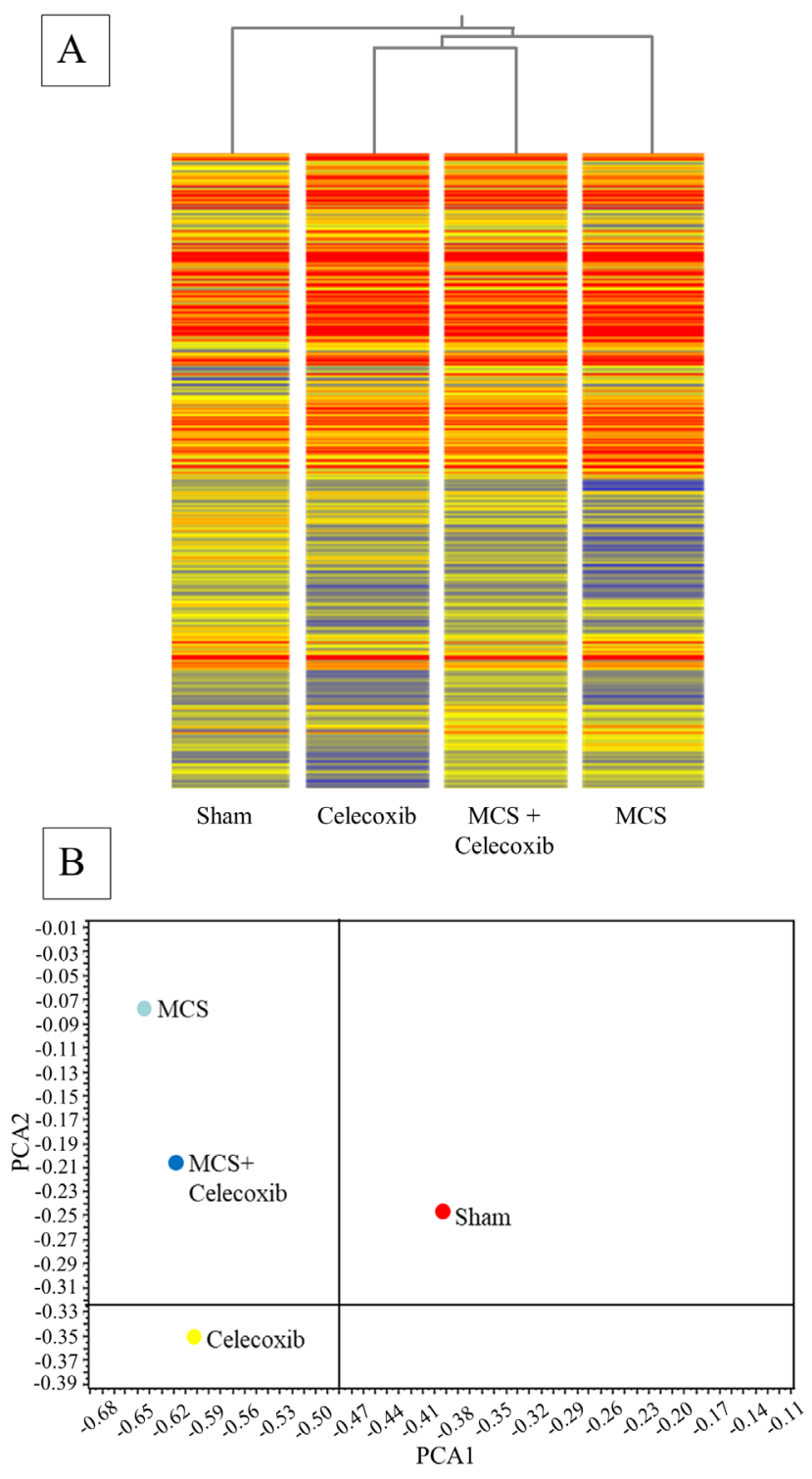

Figure 4: HCA (A) and bidimensional PCA (B) comparing the expression profiles of miRNAs in the blood serum of sham-exposed mice and MCS-exposed mice, either untreated or treated with celecoxib as described in the legend to Figure 2. 
Figure 1), and of an evident spot in the heart, which was not discernible in the liver. Administration of celecoxib to MCS-exposed mice resulted in a sharp reduction of DRZs in both lung and heart. While the celecoxib-related spots were no longer detectable in the lung, also because they were partially masked by the DRZ, the same celecoxib-related spot detected in the heart of smoke-free mice was attenuated but still visible in the heart of MCS-exposed mice.

Table 4 reports the levels of bulky DNA adducts (means \pm SE of 10 mice per gender) in the three examined organs. In the lung, exposure of mice to MCS caused a considerable and statistically significant increase of DNA adduct levels in both males (10.7-fold) and females (12.1fold), with an average 11.5-fold increase in combined genders. Likewise, exposure of mice to MCS caused a considerable and statistically significant increase of DNA adduct levels in in the heart of both males (4.6-fold) and females (5.9-fold), with an average 5.1-fold increase in combined genders. The slight differences between males and females were not statistically significant.

Although to a lower extent, being attributable to isolated spots rather than to a DRZ, the increases of
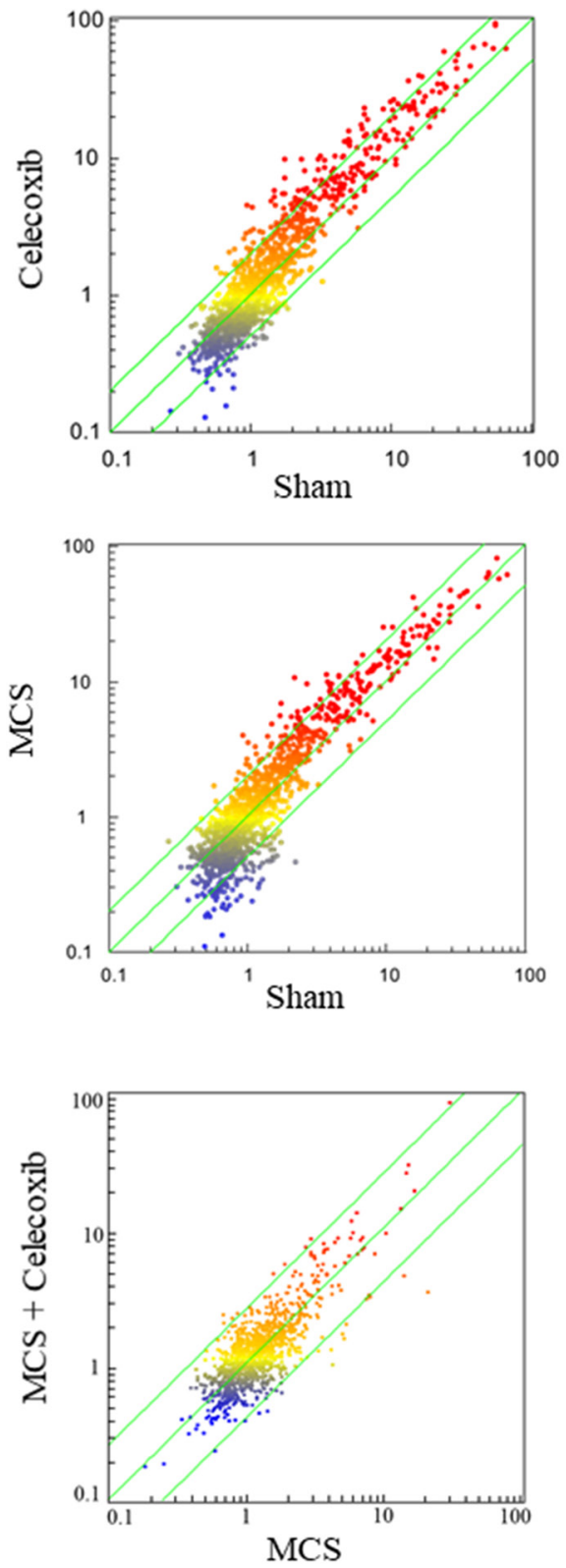

Figure 5: SPAs comparing the expression of 1,135 miRNAs in the blood serum of sham-exposed mice vs. either celecoxib-treated mice (upper panel) or MCS-exposed mice (middle panel) or MCS + celecoxib vs. mice exposed to MCS in the absence of celecoxib (bottom panel). Each dot represents a miRNA, whose expression intensity can be inferred from the position in the $\mathrm{x}$ - and $\mathrm{y}$-axes according to a color scale (blue, low; yellow, medium; orange to red, high). The diagonal belts indicate the 2 -fold variation intervals. 
Table 3: Fold variations, main functions, and tissue specificity of miRNAs that were significantly modulated in the blood serum of Swiss H mice, either treated with celecoxib (left column) or exposed to MCS (right column), as compared with sham-exposed mice

\begin{tabular}{|c|c|c|c|c|c|}
\hline \multirow[b]{2}{*}{ miRNA } & \multicolumn{3}{|c|}{ Fold variation } & \multirow[b]{2}{*}{ Function } & \multirow[b]{2}{*}{ Tissue specificity } \\
\hline & $\begin{array}{l}\text { Celecoxib/ } \\
\text { Sham }\end{array}$ & $\begin{array}{l}\text { MCS/ } \\
\text { Sham }\end{array}$ & $\begin{array}{c}\text { MCS/ } \\
\text { MCS+Celecoxib }\end{array}$ & & \\
\hline miR-9 & - & 3.12 & & Apoptosis & Brain \\
\hline $\mathrm{miR}-21 / \mathrm{miR}-21 \mathrm{a}$ & 2.65 & 2.25 & & $\begin{array}{l}\text { Tumor suppressor gene PTEN, } \\
\text { cell proliferation }\end{array}$ & $\begin{array}{l}\text { Lung, kidney, bladder, } \\
\text { liver }\end{array}$ \\
\hline miR-30a & - & 3.02 & 2.75 & $\begin{array}{l}\text { Intercellular adhesion, protein } \\
\text { repair, NFkB activation, cell } \\
\text { cycle, EGF activation, stem cell } \\
\text { recruitment, multidrug resistance }\end{array}$ & Kidney, lung, heart \\
\hline $\operatorname{miR}-125 b$ & 2.64 & 1.54 & & $\begin{array}{l}\text { Oncogene } E R B B \text {, vitamin D } \\
\text { receptor, inflammation, gene } \\
\text { transcription }\end{array}$ & $\begin{array}{l}\text { Lung, cervix, brain, ovary, } \\
\text { prostate, bladder }\end{array}$ \\
\hline $\begin{array}{l}\operatorname{miR}-181 / \\
\operatorname{miR}-181 b\end{array}$ & 2.89 & 2.79 & & $\mathrm{NF} \kappa \mathrm{B}$ stress response & $\begin{array}{l}\text { Brain, thymus, kidney, } \\
\text { lung }^{\mathrm{a}}\end{array}$ \\
\hline miR-184 & - & 3.44 & & Cell differentiation & $\begin{array}{l}\text { Epithelia, eye, tongue, } \\
\text { brain, lung }\end{array}$ \\
\hline miR-185 & 2.70 & 1.86 & & $\begin{array}{c}\text { Cell proliferation, cholesterol } \\
\text { metabolism }\end{array}$ & $\begin{array}{l}\text { Liver, breast, prostate, } \\
\text { ovary }\end{array}$ \\
\hline miR-208 & 2.63 & - & & Heart damage & Heart, lung ${ }^{\mathrm{a}}$ \\
\hline $\operatorname{miR}-211$ & - & 4.35 & 2.88 & $\begin{array}{l}\text { Stress response, oncogene (TGF) } \\
\text { suppression }\end{array}$ & Skin, pancreas \\
\hline miR-222 & 2.42 & 1.53 & & Angiogenesis, cell proliferation & Prostate, lung, bladder \\
\hline miR-296 & 2.83 & 3.05 & & $\begin{array}{l}\text { Thioredoxin and cysteine } \\
\text { synthesis (antioxidants), } \\
\text { inflammation }\end{array}$ & $\begin{array}{l}\text { Muscle, prostate, lung, } \\
\text { bladder }\end{array}$ \\
\hline $\operatorname{miR}-301 \mathrm{a}$ & 2.60 & 2.59 & & $\begin{array}{c}\text { Stress response, oncogene } \\
\text { activation }\end{array}$ & $\begin{array}{l}\text { Liver, stomach, pancreas, } \\
\text { lunga }^{\mathrm{a}}\end{array}$ \\
\hline $\operatorname{miR}-320$ & - & 3.28 & & $\begin{array}{l}\text { Protein repair, intracellular } \\
\text { trafficking, cell proliferation }\end{array}$ & Bladder, cervix, liver, lung \\
\hline miR-328 & 2.53 & - & & Stem cell differentiation & Intestine, heart \\
\hline miR-329 & - & 3.22 & & Cell proliferation, coagulation & Platelet, brain, lung ${ }^{\mathrm{a}}$ \\
\hline miR-335 & 2.40 & 2.42 & 2.51 & Cell proliferation, apoptosis & Lung \\
\hline miR-341 & - & 3.31 & & Cell differentiation & Lung $^{\mathrm{a}}$ \\
\hline miR-361 & 2.88 & 1.88 & & Angiogenesis & Blood vessels \\
\hline $\operatorname{miR}-374 b$ & - & 3.00 & 2.63 & Stress response & Lung \\
\hline miR-379 & 2.92 & 1.87 & & $\begin{array}{l}\text { Signal transduction, ATP } \\
\text { metabolism }\end{array}$ & Liver \\
\hline $\operatorname{miR}-490$ & 2.48 & - & & Stress response, cell proliferation & Lung \\
\hline $\begin{array}{l}\operatorname{miR}-551 / \\
\operatorname{miR}-551 b\end{array}$ & 2.43 & 1.48 & & $\begin{array}{l}\text { DNA repair, inflammation, cell } \\
\text { proliferation }\end{array}$ & Liver \\
\hline
\end{tabular}

(Continued) 


\begin{tabular}{|c|c|c|c|c|c|}
\hline \multirow[b]{2}{*}{ miRNA } & \multicolumn{3}{|c|}{ Fold variation } & \multirow[b]{2}{*}{ Function } & \multirow[b]{2}{*}{ Tissue specificity } \\
\hline & $\begin{array}{l}\text { Celecoxib/ } \\
\text { Sham }\end{array}$ & $\begin{array}{l}\text { MCS/ } \\
\text { Sham }\end{array}$ & $\begin{array}{c}\text { MCS/ } \\
\text { MCS+Celecoxib }\end{array}$ & & \\
\hline miR-695 & 2.90 & 2.27 & & NA & Lung $^{\mathrm{a}}$ \\
\hline miR-802 & 0.39 & - & & Glucose metabolism & Liver \\
\hline $\operatorname{miR}-804$ & 2.86 & 2.36 & & $\begin{array}{l}\text { Cell proliferation, collagen } \\
\text { production, Ras activation }\end{array}$ & Liver, lung \\
\hline miR-1199 & - & 3.13 & 2.62 & NA & Lung $^{\mathrm{a}}$ \\
\hline miR-1224 & - & 3.66 & & $\begin{array}{c}\text { Cell proliferation inhibition, } \\
\text { angiogenesis }\end{array}$ & $\begin{array}{c}\text { Liver, blood vessels, } \\
\text { lung }^{\mathrm{a}}\end{array}$ \\
\hline $\operatorname{miR}-1298$ & - & 5.81 & & Cell proliferation, apoptosis & Brain \\
\hline miR-1894 & - & 0.43 & & Cell proliferation, migration & Breast \\
\hline $\operatorname{miR}-1900$ & - & 2.39 & & Cell homeostasis & NA \\
\hline miR-1934 & - & 4.13 & & Inflammatory response & Adipose tissue \\
\hline $\operatorname{miR}-1964$ & 2.61 & & & NA & NA \\
\hline miR-1983 & - & 2.38 & & Aldosterone signaling pathway & Kidney \\
\hline miR-3068 & - & 2.56 & 2.12 & NA & NA \\
\hline $\operatorname{miR}-3080$ & - & 4.93 & 2.33 & NA & NA \\
\hline
\end{tabular}

NA, not available. ${ }^{\mathrm{a}}$ This study.

DNA adduct levels in smoke-free mice treated with celecoxib were evident and statistically significant both in the lung (2.9-fold in males, 2.5-fold in females, and 2.7-fold in combined genders) and in the heart (2.1-fold in males, 2.4-fold in females, and 2.2-fold in combined genders). On the other hand, administration of celecoxib significantly attenuated DNA adduct levels in the lung of MCS-exposed mice (1.5-fold decrease in males, 1.7fold decrease in males, and 1.6-fold decrease in combined genders as compared with MCS-exposed mice in the absence of celecoxib). A similar protective effect was detected in the heart of MCS-exposed mice, an effect that was not statistically significant in males (1.1-fold decrease) but reached the statistically significant threshold in both females (1.5-fold decrease) and combined genders (1.3-fold decrease). In any case, DNA adduct levels in both lung and heart of MCS-exposed mice treated with celecoxib were still much higher than those detected in sham-exposed mice. In the liver, the levels of DNA adducts in mice treated with either MCS and/or celecoxib varied to a statistically significant extent but the differences were very modest and of the same order of magnitude for all treatments. In fact, the increases over sham-exposed mice were 1.5-fold in males, 1.6-fold in both females and combined genders of MCS-exposed mice in the absence of celecoxib; 1.3 -fold in males, 1.5 -fold in females, and 1.4fold in combined genders of MCS-free mice treated with celecoxib; and 1.3-fold in males, 1.5 -fold in females, and 1.4-fold in mixed genders of MCS-exposed mice treated with celecoxib.

\section{Study 3. Modulation by celecoxib of miRNA expression profiles in 10 organs and 3 body fluids of young Swiss ICR (CD-1) mice, either smoke-free or MCS-exposed}

\section{Survival and body weights}

All mice survived after 8 weeks of treatment. The body weights in sham-exposed mice at the beginning of the study were $38.3 \pm 0.83$ in males and $28.8 \pm 0.82$ in females and grew progressively until reaching a plateau after 3 weeks. After 8 weeks, the body weights were 42.3 \pm 1.09 in males and $37.5 \pm 1.16$ in females. From the $3 \mathrm{rd}$ week onwards, exposure to MCS resulted in a slight but statistically significant loss of body weight, which after 8 weeks was $39.4 \pm 0.70$ in males $(P<0.05$ as compared to sham) and $31.7 \pm 1.22$ in females $(P<0.01)$.

As compared with sham-exposed mice, administration of celecoxib at high dose $(1,600 \mathrm{mg} / \mathrm{kg}$ diet) did not significantly affect the body weight, which was $42.1 \pm 0.61$ in males and $31.5 \pm 0.98$ in females. Likewise, administration of celecoxib at low dose $(20 \mathrm{mg} /$ $\mathrm{kg}$ diet) to smoke-free female mice did not significantly affect the body weight, which was $32.6 \pm 1.82$. The slight body weight loss caused by MCS was not significantly affected by administration of celecoxib either at high dose 
(34.6 \pm 1.55 in males and $26.7 \pm 0.56$ in females) or at low dose $(30.9 \pm 1.24$ in females $)$.

\section{Effect of high dose celecoxib on miRNA expression in 10 organs and 3 body fluids of mice, either sham-exposed or MCS-exposed}

Administration of high dose celecoxib $(1,600 \mathrm{mg} / \mathrm{kg}$ diet) altered the position of miRNA profiles as compared to sham-exposed mice, as evaluated by bidimensional PCA (Figure 7C vs. Figure 7A). The organs changing the PCA quadrant compared to Sham-treated mice as a consequence of celecoxib administration were the stomach, colon, spleen, kidney, lung, and skeletal muscle. The influence of celecoxib on miRNA expression in body fluids was less remarkable. The organs changing PCA quadrant as a consequence of celecoxib administration to MCS-exposed mice (Figure 7D, as compared to MCSexposed mice in the absence of the drug (Figure 7B), were lung, kidney, bladder, and muscle. The effects of celecoxib were also detectable in body fluids of MCS-exposed mice, especially in urine and BALF.

The celecoxib organotropism was evaluated with more details by comparative SPA (Figure 8). According to the number of miRNAs varying their expression more than 2-fold as a consequence of celecoxib treatment

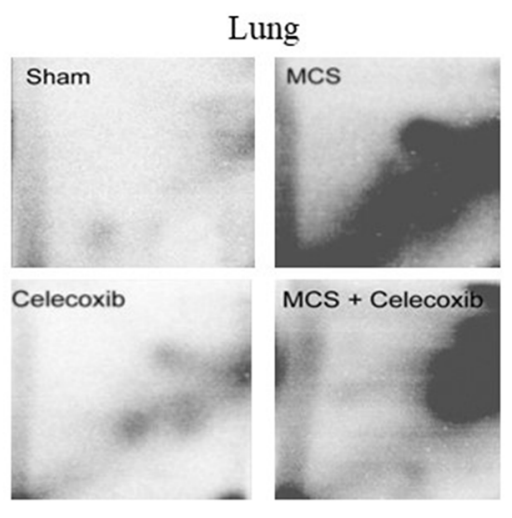

Heart

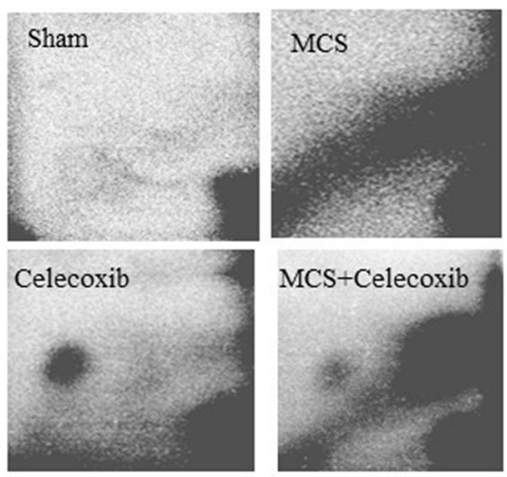

Liver
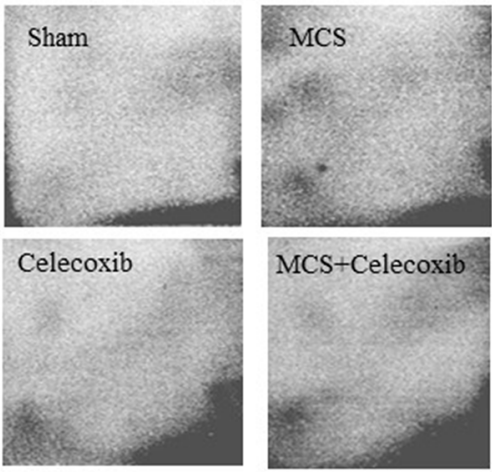

Figure 6: Examples of ${ }^{32} \mathrm{P}$ autoradiographs obtained by testing the lung, heart, and liver DNA from ICR (CD-1) mice, either untreated (sham-exposed) or treated with celecoxib for 6 weeks after weanling or exposed to MCS for 10 weeks since birth, in the absence of celecoxib, or exposed to MCS and treated with celecoxib. 
Table 4: Bulky DNA adducts evaluated by ${ }^{32} \mathrm{P}$ postlabeling in the lungs, heart and liver of 80 ICR (CD-1) mice, as related to gender, exposure to MCS, and treatment with celecoxib

\begin{tabular}{|c|c|c|c|c|}
\hline \multirow{2}{*}{ Treatment } & \multirow{2}{*}{ Gender } & \multicolumn{3}{|c|}{ Adducts $/ 10^{8}$ nucleotides } \\
\hline & & Lung & Heart & Liver \\
\hline \multirow[t]{3}{*}{ Sham } & $M$ & $1.5 \pm 0.18$ & $1.6 \pm 0.09$ & $1.2 \pm 0.09$ \\
\hline & $\mathrm{F}$ & $1.5 \pm 0.20$ & $1.5 \pm 0.05$ & $1.2 \pm 0.09$ \\
\hline & $M+F$ & $1.5 \pm 0.12$ & $1.6 \pm 0.05$ & $1.2 \pm 0.06$ \\
\hline \multirow[t]{3}{*}{ Celecoxib } & M & $4.4 \pm 0.56^{\mathrm{c}}$ & $3.3 \pm 0.18^{c}$ & $1.6 \pm 0.12^{\mathrm{a}}$ \\
\hline & $\mathrm{F}$ & $3.7 \pm 0.31^{\mathrm{c}}$ & $3.6 \pm 0.37^{\mathrm{c}}$ & $1.8 \pm 0.08^{\mathrm{c}}$ \\
\hline & $M+F$ & $4.0 \pm 0.31^{\mathrm{c}}$ & $3.4 \pm 0.17^{\mathrm{c}}$ & $1.7 \pm 0.08^{\mathrm{a}}$ \\
\hline \multirow[t]{3}{*}{ MCS } & M & $16.1 \pm 0.97^{\mathrm{c}}$ & $7.4 \pm 0.54^{\mathrm{c}}$ & $1.8 \pm 0.17^{\mathrm{b}}$ \\
\hline & $\mathrm{F}$ & $18.2 \pm 1.46^{\mathrm{c}}$ & $8.9 \pm 0.73^{\mathrm{c}}$ & $1.9 \pm 0.17^{\mathrm{b}}$ \\
\hline & $M+F$ & $17.2 \pm 0.87^{\mathrm{c}}$ & $8.2 \pm 0.45^{\mathrm{c}}$ & $1.9 \pm 0.13^{\mathrm{c}}$ \\
\hline \multirow[t]{3}{*}{ MCS + Celecoxib } & M & $10.5 \pm 0.89^{\mathrm{c}, \mathrm{e}}$ & $6.9 \pm 0.35^{\mathrm{c}}$ & $1.6 \pm 0.11^{\mathrm{a}}$ \\
\hline & $\mathrm{F}$ & $10.8 \pm 1.09^{\mathrm{c}, \mathrm{e}}$ & $6.1 \pm 0.25^{\mathrm{c}, \mathrm{d}}$ & $1.8 \pm 0.10^{\mathrm{c}}$ \\
\hline & $\mathrm{M}+\mathrm{F}$ & $10.7 \pm 0.69^{\mathrm{c}, \mathrm{e}}$ & $6.4 \pm 0.23^{\mathrm{c}, \mathrm{d}}$ & $1.7 \pm 0.08^{c}$ \\
\hline
\end{tabular}

The results are means $\pm \mathrm{SE}$ of the results obtained in 10 mice per group.

Statistical analysis: ${ }^{\mathrm{a}} P<0.05,{ }^{\mathrm{b}} P<0.01$, and ${ }^{\mathrm{c}} P<0.001$, as compared with sham-exposed mice; ${ }^{\mathrm{d}}<0.01$ and ${ }^{\mathrm{e}} P<0.001$, as compared with MCS-exposed mice.

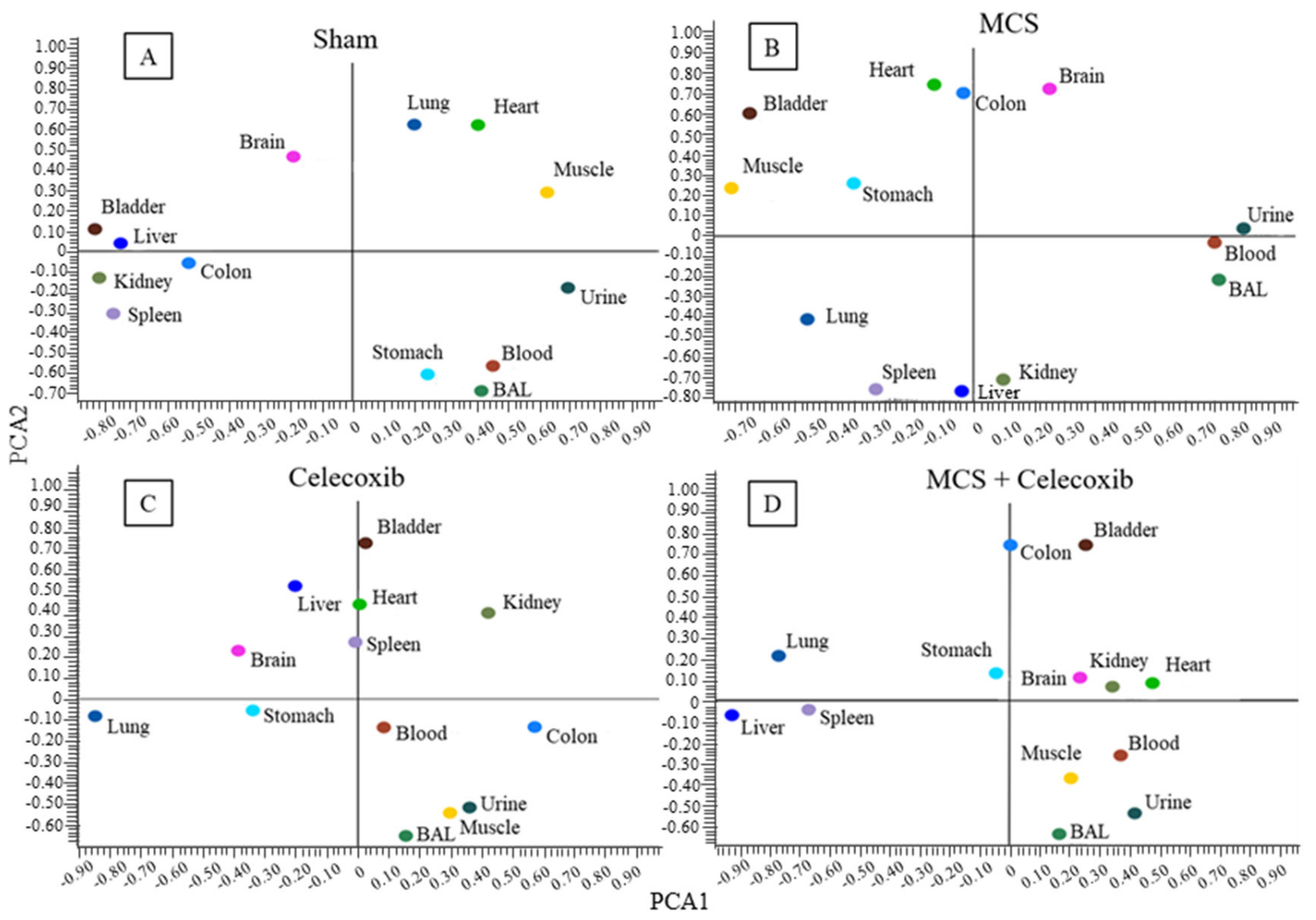

Figure 7: Bidimensional PCA comparing the expression profiles of miRNAs in 10 organs and 3 body fluids of adult ICR (CD-1) mice, either sham-exposed (A) or exposed to MCS for 8 weeks (B), and either administered celecoxib to smoke-free mice (C) or MCS-exposed mice (D). 
(i.e., being located outside the diagonal area limited by green lines in Figure 8), it appears that the preferentially targeted organs were lung and bladder. An intermediate effect was detected in liver, kidney, spleen, colon, and stomach; only minimal effects were observed in heart, skeletal muscle, and brain. miRNA expression in body fluids was markedly affected by celecoxib treatment, especially in blood and BAL, and remarkable effects were also detected in urine. Figure 9 shows the overall protective effects of celecoxib from MCS as evaluated by SPA. According to the number of miRNAs varying their expression more than 2-fold as a consequence of celecoxib administration to MCS-exposed mice (i.e., being located outside the diagonal area limited by green lines in Figure 9), the preferentially protected organs by celecoxib were bladder, kidney, and spleen; intermediate effects were detectable in stomach, colon, skeletal muscle, heart, liver, and lung; no effect was detectable in the brain. As to body fluids, blood and BAL were more sensitive than urine in detecting the protective effects of celecoxib against miRNA alteration induced by MCS.

Table 5 provides a list reporting the identity and functions of miRNAs modulated by celecoxib in 9 organs and 3 body fluids of ICR (CD-1) mice, either shamexposed (superscripts a) or MCS-exposed (superscripts b). The brain is not reported in that table because no brain miRNA was significantly modulated by celecoxib. As inferred from Table 5, 30 miRNAs were modulated by celecoxib in the urinary bladder (upregulated/ downregulated in MCS-free mice: 0/10; upregulated/ downregulated in MCS-exposed mice: 8/12); 27 in kidney $(7 / 20 ; 0 / 0) ; 20$ in stomach $(2 / 12 ; 3 / 3) ; 18$ in liver $(0 / 15$; $2 / 1) ; 18$ in blood serum $(2 / 11 ; 2 / 3) ; 17$ in spleen $(2 / 7 ; 1 / 7)$; 16 in skeletal muscle $(0 / 0 ; 6 / 10) ; 15$ in lung $(14 / 0 ; 0 / 1) ; 7$ in colon $(1 / 4 ; 0 / 2)$ and in $\operatorname{BALF}(2 / 3 ; 0 / 2) ; 3$ in heart $(0 / 2$; $0 / 1)$ and urines $(0 / 3 ; 0 / 0)$; and 0 in brain.

Thus, on the whole upregulation of miRNA expression by celecoxib in smoke-free mice was by far prevalent in the lung, whereas the balance was in favor of downregulation in other organs, such as urinary bladder, kidney, stomach, and spleen, and body fluids (blood serum and urines). In MCS-exposed mice the number of miRNAs modulated by celecoxib was lower as compared with MCSfree mice, with the exception of the urinary bladder and skeletal muscle, in which downregulation was prevailing.

Several miRNAs were upregulated in organs of MCS-free mice while being downregulated in the same organs of MCS-exposed mice, which reflects the ability of celecoxib to alter the physiological miRNA expression but, at the same time, to counteract MCS-related alterations. In addition, a number of miRNAs, often clustered
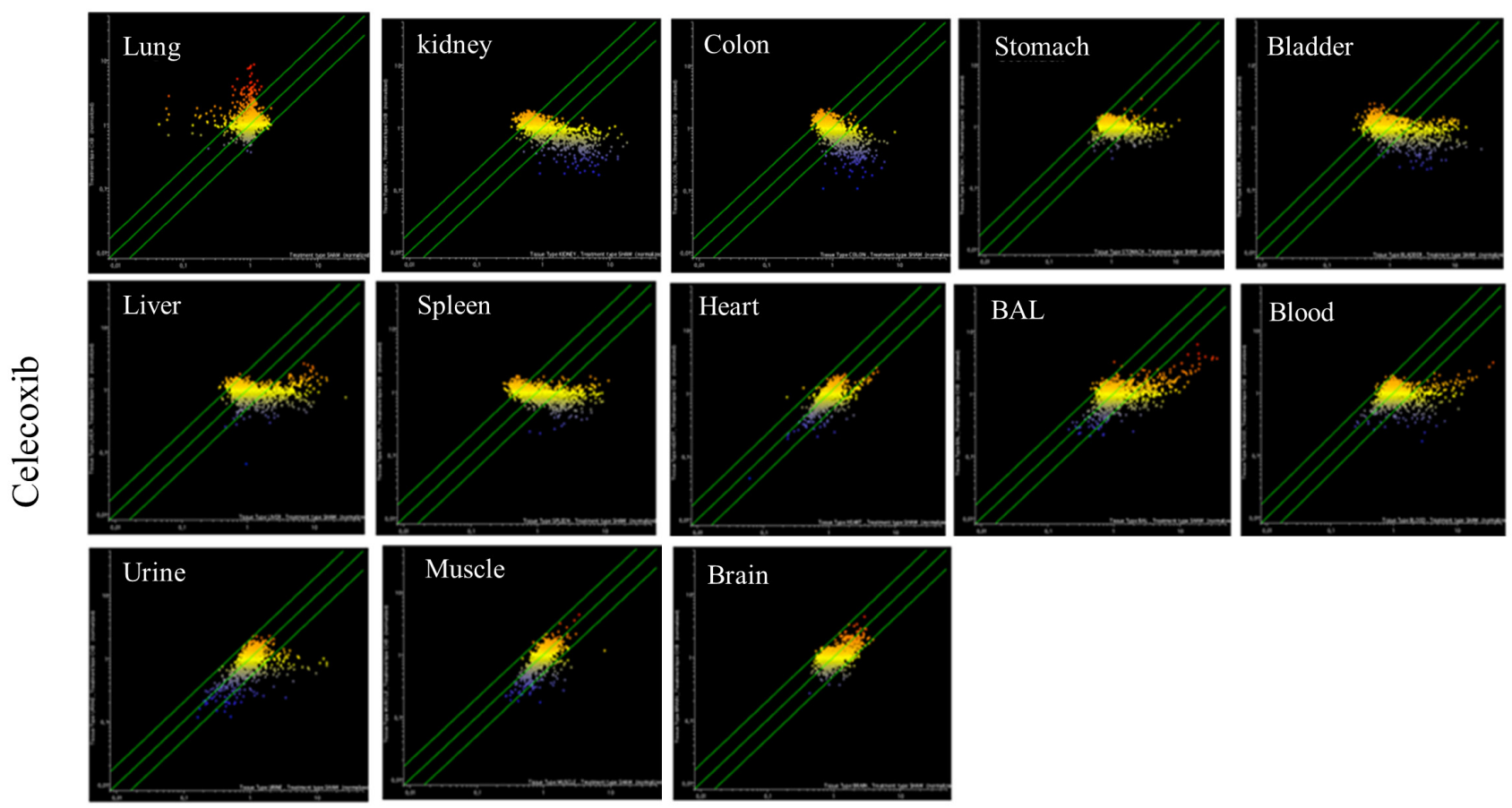

Sham

Figure 8: SPAs comparing the expression of 1,135 pulmonary miRNAs in 10 organs and 3 body fluids of ICR (CD-1) mice in celecoxib-treated vs. sham-exposed mice. Each dot represents a miRNA, whose expression intensity can be inferred from the position in the $\mathrm{x}$ - and $\mathrm{y}$-axes according to a color scale (blue, low; yellow, medium; orange to red, high). The diagonal belts indicate the 2 -fold variation intervals. Symbols falling in the upper left area denote miRNA upregulation by celecoxib, and those falling in the bottom right area denote miRNA downregulation by celecoxib. 
in miRNA families, were modulated by celecoxib in multiple targets, sometimes with high fold variations. For instance, members of the miR-30 family were extensively downregulated by celecoxib. In fact, this drug downregulated miR-30b in the liver, heart, kidney and colon of MCS-free mice as well as in the heart, spleen, and urinary bladder of MCS-exposed mice; miR-30c-2-3p was downregulated by celecoxib in the liver (9-fold) and kidney (14-fold) of MCS-free mice and in the spleen and urinary bladder (7-fold) of MCS-exposed mice; miR-30c-2-5p was downregulated in the heart, kidney (13-fold), spleen (7fold), urinary bladder (10-fold), stomach, blood serum and BALF of MCS-free mice and in the skeletal muscle and colon of MCS-exposed mice; miR-30e was downregulated in the liver (10-fold), kidney (8-fold), urinary bladder (8-fold), and blood serum of MCS-free mice, whereas it was upregulated in the lung, urinary bladder (6-fold) and skeletal muscle (9-fold) of MCS-exposed mice. Within the miR-125 family, celecoxib downregulated miR-125a in the liver, kidney, spleen, and stomach of MCS-free mice and in the skeletal muscle and stomach of MCSexposed mice, in which this miRNA was upregulated in the liver; miR-125b was downregulated by celecoxib in the lung, kidney, spleen and stomach of MCS-free mice and in the urinary blood, skeletal muscle (11-fold) and stomach (9-fold) of MCS-exposed mice. Within the miR-
185 family, celecoxib downregulated miR-185-3p in the kidney and stomach of MCS-free mice and in the spleen and skeletal muscle of MCS-exposed mice; miR-185-5p was downregulated in the liver, kidney (as much as 25fold), urinary bladder (20-fold), colon (8-fold) and blood serum of MCS-free mice and in the lung, spleen, urinary bladder (14-fold) and blood serum of MCS-exposed mice. Within the miR-301 family, celecoxib downregulated miR301 in the liver, kidney (7-fold), urinary bladder (8-fold) and colon (6-fold) of MCS-free mice and miR-301b in the liver, kidney, urinary bladder and skeletal muscle of MCSfree mice and in the urinary bladder of MCS-exposed mice. Furthermore, celecoxib downregulated miR-196a$5 \mathrm{p}$ in the liver, kidney, spleen, urinary bladder and colon of MCS-free mice, whereas the levels of the same miRNA were increased in blood serum. Celecoxib downregulated miR-208a-5p in the kidney, stomach, BALF and urines of MCS-free mice and in the urinary bladder of MCSexposed mice. It caused a strong upregulation of miR-361 in the lung (8-fold), whereas it downregulated this miRNA in the liver, kidney, stomach and blood serum of MCS-free mice as well as in the spleen and skeletal muscle of MCSexposed mice. miR-511 was upregulated by celecoxib in the kidney of MCS-free mice and in the liver an skeletal muscle (5-fold) of MCS-exposed mice, in which this miRNA was downregulated in the stomach. miR-695 was

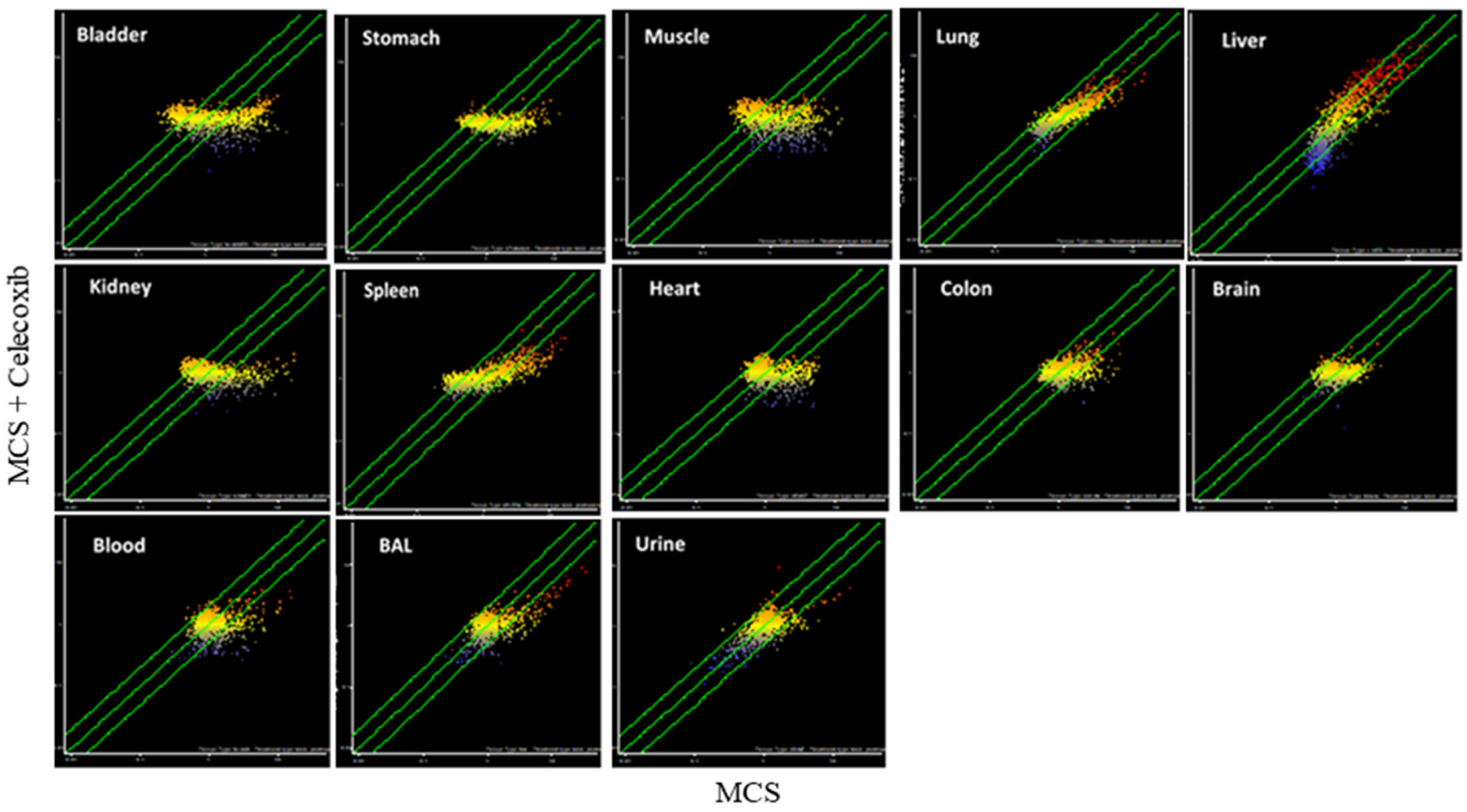

Figure 9: SPAs comparing the expression of 1,135 pulmonary miRNAs in 10 organs and 3 body fluids of ICR (CD-1) mice, either MCS-exposed and treated with celecoxib or MCS-exposed in the absence of celecoxib. Each dot represents a miRNA, whose expression intensity can be inferred from the position in the $\mathrm{x}$ - and $\mathrm{y}$-axes according to a color scale (blue, low; yellow, medium; orange to red, high). The diagonal belts indicate the 2-fold variation intervals. Symbols falling in the upper left area denote miRNA upregulation by celecoxib, and those falling in the bottom right area denote miRNA downregulation by celecoxib. 
Table 5: MiRNAs modulated by high dose celecoxib $(1,600 \mathrm{mg} / \mathrm{Kg}$ diet) in 9 organs and 3 body fluids of female ICR (CD-1) mice, either sham-exposed or MCS-exposed

\begin{tabular}{|c|c|c|c|c|c|c|c|c|c|c|c|c|c|}
\hline miRNA & Lung & Liver & Heart & Kidney & Spleen & $\begin{array}{l}\text { Urinary } \\
\text { bladder }\end{array}$ & $\begin{array}{c}\text { Skeletal } \\
\text { muscle }\end{array}$ & Colon & Stomach & $\begin{array}{l}\text { Blood } \\
\text { serum }\end{array}$ & BALF & Urine & Main functions \\
\hline miR-21a & & & & & & & & & $0.39^{\mathrm{a}}$ & $0.27^{\mathrm{a}}$ & & & $\begin{array}{c}\text { Tumor suppressor gene PTEN, cell } \\
\text { proliferation }\end{array}$ \\
\hline miR-30a & $2.04^{\mathrm{a}}$ & & & & & & & & & & & & $\begin{array}{l}\text { Intercellular adhesion, protein repair, NFkB } \\
\text { activation, cell cycle, EGF activation, stem } \\
\text { cell recruitment, multidrug resistance }\end{array}$ \\
\hline miR-30b & & $0.26^{\mathrm{a}}$ & $\begin{array}{l}0.41^{a} \\
0.36^{\mathrm{b}}\end{array}$ & $0.25^{a}$ & $0.31^{\mathrm{b}}$ & $0.22^{\mathrm{b}}$ & & $0.23^{a}$ & & & & & $\begin{array}{l}\text { Intercellular adhesion, protein repair, NFkB } \\
\text { activation, cell cycle, EGF activation, stem } \\
\text { cell recruitment, multidrug resistance }\end{array}$ \\
\hline $\operatorname{miR}-30 c-1-3 p$ & & & & & & $0.33^{\mathrm{b}}$ & & & $0.25^{\mathrm{a}}$ & & & & $\begin{array}{l}\text { Intercellular adhesion, protein repair, NFkB } \\
\text { activation, cell cycle, EGF activation, stem } \\
\text { cell recruitment, multidrug resistance }\end{array}$ \\
\hline $\operatorname{miR}-30 c-2-3 p$ & & $0.11^{\mathrm{a}}$ & & $0.07^{\mathrm{a}}$ & $0.30^{\mathrm{b}}$ & $0.14^{\mathrm{b}}$ & & & & & & & $\begin{array}{l}\text { Intercellular adhesion, protein repair, NFkB } \\
\text { activation, cell cycle, EGF activation, stem } \\
\text { cell recruitment, multidrug resistance }\end{array}$ \\
\hline $\operatorname{miR}-30 c-5 p$ & & & $0.46^{\mathrm{a}}$ & $0.08^{\mathrm{a}}$ & $0.15^{\mathrm{a}}$ & $0.10^{\mathrm{a}}$ & $0.23^{\mathrm{b}}$ & $0.33^{\mathrm{b}}$ & $0.40^{\mathrm{a}}$ & $0.26^{\mathrm{a}^{*}}$ & $0.26^{\mathrm{a}}$ & & $\begin{array}{l}\text { Intercellular adhesion, protein repair, NFkB } \\
\text { activation, cell cycle, EGF activation, stem } \\
\text { cell recruitment, multidrug resistance }\end{array}$ \\
\hline miR-30d & $2.64^{\mathrm{a}}$ & & & & & & $2.58^{\mathrm{b}}$ & & & & & & $\begin{array}{l}\text { Intercellular adhesion, protein repair, NFkB } \\
\text { activation, cell cycle, EGF activation, stem } \\
\text { cell recruitment, multidrug resistance }\end{array}$ \\
\hline miR-30e & $3.10^{\mathrm{a}}$ & $0.10^{\mathrm{a}}$ & & $0.12^{\mathrm{a}}$ & & $\begin{array}{l}0.13^{\mathrm{b}} \\
0.12^{\mathrm{a}}\end{array}$ & $0.11^{\mathrm{b}}$ & & & $0.28^{\mathrm{a}}$ & & & $\begin{array}{l}\text { Intercellular adhesion, protein repair, NFkB } \\
\text { activation, cell cycle, EGF activation, stem } \\
\text { cell recruitment, multidrug resistance }\end{array}$ \\
\hline miR-106a & & & & & & & $2.65^{\mathrm{b}}$ & & & $2.03^{\mathrm{a}}$ & & & $\begin{array}{c}\text { Cell adhesion, TNF activation, stress } \\
\text { response }\end{array}$ \\
\hline $\operatorname{miR}-125 \mathrm{a}$ & & $\begin{array}{l}0.35^{\mathrm{a}} \\
2.08^{\mathrm{b}}\end{array}$ & & $0.31^{\mathrm{a}}$ & $0.49^{\mathrm{a}}$ & & $0.22^{\mathrm{b}}$ & & $\begin{array}{l}0.32^{\mathrm{a}} \\
0.35^{\mathrm{b}}\end{array}$ & & & & $\begin{array}{l}\text { Oncogene ERBB, vitamin D receptor, } \\
\text { inflammation, gene transcription }\end{array}$ \\
\hline $\operatorname{miR}-125 b$ & $2.16^{\mathrm{a}}$ & & & $0.23^{\mathrm{a}}$ & $0.29^{\mathrm{a}}$ & $0.42^{\mathrm{b}}$ & $0.09^{\mathrm{b}}$ & & $\begin{array}{l}0.28^{\mathrm{a}} \\
0.11^{\mathrm{b}}\end{array}$ & & & & $\begin{array}{l}\text { Oncogene ERBB, vitamin D receptor, } \\
\text { inflammation, gene transcription }\end{array}$ \\
\hline $\operatorname{miR}-181 \mathrm{~b}$ & $4.08^{\mathrm{a}}$ & & & & & $2.43^{\mathrm{b}}$ & & & $2.60^{\mathrm{b}}$ & & $0.48^{\mathrm{a}}$ & & NFkB stress response \\
\hline $\operatorname{miR}-181 c-3 p$ & & & & & & & & & $0.40^{\mathrm{a}}$ & & & & NFkB stress response \\
\hline $\operatorname{miR}-181 c-5 p$ & & & & & & $2.83^{\mathrm{b}}$ & $4.78^{\mathrm{b}}$ & & & & & & NFkB stress response \\
\hline $\operatorname{miR}-181 \mathrm{~d}$ & $2.78^{\mathrm{a}}$ & & & & & $2.73^{\mathrm{b}}$ & & & $0.46^{\mathrm{a}}$ & & & & NFkB stress response \\
\hline $\operatorname{miR}-185-3 p$ & & & & $0.39^{\mathrm{a}}$ & $0.29^{\mathrm{b}}$ & & $0.37^{\mathrm{b}}$ & & $0.29^{\mathrm{a}}$ & & & & Cell proliferation, cholesterol metabolism \\
\hline $\operatorname{miR}-185-5 p$ & $0.47^{\mathrm{b}^{*}}$ & $0.06^{\mathrm{a}}$ & & $0.04^{\mathrm{a}}$ & $0.48^{\mathrm{b}}$ & $\begin{array}{l}0.07^{\mathrm{b}} \\
0.05^{\mathrm{a}}\end{array}$ & & $0.12^{\mathrm{a}}$ & & $\begin{array}{c}0.38^{\mathrm{a}^{*}} \\
0.35^{\mathrm{b}}\end{array}$ & & & Cell proliferation, cholesterol metabolism \\
\hline miR-193b & & $0.30^{\mathrm{b}}$ & & $2.11^{\mathrm{a}}$ & & & & & & & & & Signal transduction \\
\hline miR-196a-3p & & & & & $0.20^{\mathrm{a}}$ & & & & & & & & TGF-beta \\
\hline miR-196a-5p & & $0.25^{\mathrm{a}}$ & & $0.27^{\mathrm{a}}$ & $0.28^{\mathrm{a}}$ & $0.18^{\mathrm{b}}$ & & $0.34^{\mathrm{a}}$ & & $2.13^{\mathrm{b}}$ & & & TGF-beta \\
\hline miR-208a-3p & & & & & $0.15^{\mathrm{a}}$ & & & & & & & & Heart damage \\
\hline miR-208a-5p & & & & $0.21^{\mathrm{a}}$ & & $0.18^{\mathrm{b}}$ & & & $0.43^{\mathrm{a}}$ & & $0.47^{\mathrm{a}}$ & $0.45^{\mathrm{a}}$ & Heart damage \\
\hline $\operatorname{miR}-208 b$ & & & & $2.66^{\mathrm{a}}$ & & $0.18^{\mathrm{b}}$ & & & $2.02^{\mathrm{b}}$ & & & & Heart damage \\
\hline miR-211 & & & & & & & & & $2.30^{\mathrm{b}}$ & & & & $\begin{array}{l}\text { Stress response, oncogene (TGF) } \\
\text { suppression }\end{array}$ \\
\hline $\operatorname{miR}-222$ & & & & & & & & $2.76^{\mathrm{a}}$ & & & & & Angiogenesis, cell proliferation \\
\hline $\operatorname{miR}-290$ & & & & & & & & & & $0.15^{\mathrm{a}}$ & & $0.12^{\mathrm{a}^{*}}$ & Stem cell marker \\
\hline $\operatorname{miR}-296$ & $2.15^{\mathrm{a}^{*}}$ & & & & & & & & & & & & $\begin{array}{l}\text { Thioredoxin and cysteine synthesis } \\
\text { (antioxidants), Inflammation }\end{array}$ \\
\hline miR-301a & & $0.22^{\mathrm{a}}$ & & $0.14^{\mathrm{a}}$ & & $0.13^{\mathrm{a}}$ & & $0.18^{\mathrm{a}}$ & & & & & Stress response, oncogene activation \\
\hline $\operatorname{miR}-301 \mathrm{~b}$ & & $0.30^{\mathrm{a}}$ & & $0.41^{\mathrm{a}}$ & & $\begin{array}{l}0.43^{\mathrm{b}} \\
0.41^{\mathrm{a}}\end{array}$ & $0.30^{\mathrm{b}}$ & & & & & & Stress response, oncogene activation \\
\hline
\end{tabular}




\begin{tabular}{|c|c|c|c|c|c|c|c|c|c|c|c|c|c|}
\hline miRNA & Lung & Liver & Heart & Kidney & Spleen & $\begin{array}{l}\text { Urinary } \\
\text { bladder }\end{array}$ & $\begin{array}{l}\text { Skeletal } \\
\text { muscle }\end{array}$ & Colon & Stomach & $\begin{array}{l}\text { Blood } \\
\text { serum }\end{array}$ & BALF & Urine & Main functions \\
\hline $\operatorname{miR}-335-3 p$ & & $0.26^{\mathrm{a}}$ & & $0.24^{\mathrm{a}}$ & & & & & & $\begin{array}{l}0.25^{\mathrm{b}} \\
0.22^{\mathrm{a}}\end{array}$ & & & Cell proliferation, apoptosis \\
\hline $\operatorname{miR}-335-5 p$ & & & & $0.05^{\mathrm{a}}$ & & $0.07^{\mathrm{a}}$ & & & & & & & Cell proliferation, apoptosis \\
\hline miR-361 & $8.09^{\mathrm{a}}$ & $0.33^{\mathrm{a}}$ & & $0.20^{\mathrm{a}}$ & $0.35^{\mathrm{b}}$ & & $0.34^{\mathrm{b}}$ & & $0.23^{\mathrm{a}}$ & $0.29^{\mathrm{a}}$ & & & Angiogenesis \\
\hline $\operatorname{miR}-374 b$ & $2.06^{\mathrm{a}}$ & & & $0.48^{\mathrm{a}}$ & & & & & & & & & Cell proliferation, invasion \\
\hline miR-379 & & & & & & $0.42^{\mathrm{a}}$ & & & & & & & Signal transduction \\
\hline miR-381 & & & & & $0.42^{\mathrm{b}}$ & & & & & & & & Cell proliferation \\
\hline $\operatorname{miR}-471$ & $3.72^{\mathrm{a}}$ & $0.14^{\mathrm{a}}$ & & $2.99^{\mathrm{a}}$ & $3.20^{\mathrm{b}}$ & & & & $2.02^{\mathrm{b}}$ & $0.26^{\mathrm{a}}$ & & & NA \\
\hline $\operatorname{miR}-511-3 p$ & & & & & $0.18^{\mathrm{a}}$ & & & & & & & & Inflammation, monocyte activation \\
\hline $\operatorname{miR}-511-5 p$ & & $2.06^{b}$ & & $2.33^{\mathrm{a}}$ & & & $4.52^{\mathrm{b}}$ & & $0.43^{b}$ & & & & Inflammation, monocyte activation \\
\hline $\operatorname{miR}-551 b$ & $3.08^{\mathrm{a}^{*}}$ & & & & & & & & & & & & DNA repair, inflammation, cell proliferation \\
\hline $\operatorname{miR}-615$ & & & & $0.24^{\mathrm{a}}$ & & $3.53^{b}$ & & & & $0.33^{\mathrm{a}}$ & & & Macrophage activation \\
\hline $\operatorname{miR}-695$ & & & & $0.33^{\mathrm{a}}$ & & $0.44^{\mathrm{b}}$ & $0.17^{\mathrm{b}}$ & & $0.21^{\mathrm{a}}$ & $0.28^{\mathrm{a}}$ & $0.17^{\mathrm{a}}$ & & NA \\
\hline $\operatorname{miR}-701-3 p$ & & & & & $\begin{array}{l}2.78^{\mathrm{a}} \\
2.32^{\mathrm{b}}\end{array}$ & $4.84^{\mathrm{b}}$ & $0.25^{\mathrm{b}}$ & & & $0.47^{\mathrm{b}}$ & $0.30^{\mathrm{a}}$ & & NA \\
\hline $\operatorname{miR}-701-5 p$ & & & & & $0.30^{\mathrm{b}}$ & & & & & & & & NA \\
\hline $\operatorname{miR}-758$ & & & & & & & & & & $2.17^{b}$ & & & Cell proliferation, apoptosis \\
\hline $\operatorname{miR}-802-3 p$ & & $0.14^{\mathrm{a}}$ & & $0.16^{\mathrm{a}}$ & & $4.86^{\mathrm{b}}$ & & & $2.99^{b}$ & & & & Glucose metabolism \\
\hline miR-802-5p & & & & & & $0.22^{\mathrm{a}}$ & & & & & & & Glucose metabolism \\
\hline miR-804 & $3.71^{\mathrm{a}}$ & & & & & & & & $0.23^{\mathrm{a}}$ & & & & $\begin{array}{l}\text { Cell proliferation, } \\
\text { collagen production, Ras activation }\end{array}$ \\
\hline miR-1195 & & & & & & $2.71^{\mathrm{b}}$ & & & & & & & $\begin{array}{l}\text { MAP kinase signaling pathway, cytochrome } \\
\text { CYP2s1 activity }\end{array}$ \\
\hline miR-1199 & & & & & & $2.66^{\mathrm{b}}$ & $3.03^{\mathrm{b}}$ & & $0.21^{\mathrm{a}}$ & & & & NA \\
\hline $\operatorname{miR}-1247$ & $6.08^{\mathrm{a}}$ & & & & & & & & & & & & $\begin{array}{l}\text { Fibroblasts activation, increase of pro- } \\
\text { inflammatory gene expression }\end{array}$ \\
\hline $\operatorname{miR}-1251$ & & & & $2.63^{\mathrm{a}}$ & & & $2.41^{b}$ & & & & & & Signal transduction by targeting IGF1 \\
\hline $\operatorname{miR}-1945$ & & & & $2.89^{\mathrm{a}}$ & & & & & & & $0.45^{\mathrm{a}}$ & $0.38^{\mathrm{a}^{*}}$ & NA \\
\hline $\operatorname{miR}-1952$ & & & & & & & & $2.14^{\mathrm{b}}$ & & & & & NA \\
\hline $\operatorname{miR}-1964-3 p$ & $2.87^{\mathrm{a}}$ & & & $2.97^{\mathrm{a}}$ & & & & & & & & & NA \\
\hline miR-1964-5p & & & & $0.15^{\mathrm{a}}$ & & $\begin{array}{l}0.22^{\mathrm{b}} \\
0.14^{\mathrm{a}}\end{array}$ & $0.22^{\mathrm{b}}$ & & $0.23^{\mathrm{a}}$ & $0.13^{\mathrm{a}}$ & $\begin{array}{l}0.31^{\mathrm{b}} \\
0.17^{\mathrm{a}}\end{array}$ & & NA \\
\hline
\end{tabular}

"Also modulated by low dose celecoxib $(20 \mathrm{mg} / \mathrm{Kg}$ diet $)$. NA, not available.

The reported values indicate the fold variation of miRNA expression either in celecoxib-treated $v s$. sham-exposed mice ${ }^{a}$ or in MCS-exposed mice treated with celecoxib $v s$. MCS-exposed mice in the absence of celecoxib ${ }^{b}$.

downregulated in the kidney, stomach, blood serum and BALF of MCS-free mice and in the urinary bladder and skeletal muscle (6-fold) of MCS-exposed mice. miR-701$3 p$ was upregulated in the spleen and downregulated in the BALF of MCS-free mice, whereas it was upregulated in the spleen and urinary bladder (5-fold) and downregulated in the skeletal muscle and blood serum of MCS-exposed mice. miR-802-3p was downregulated in the liver (7-fold) and kidney (6-fold) of MCS-free mice and upregulated in the urinary bladder (5-fold) and stomach (3-fold) of MCSexposed mice. miR-1945 was upregulated in the kidney, whereas its levels decreased in both BALF and urines of MCS-free mice. miR-1964-5p was downregulated by celecoxib in the kidney (7-fold), stomach (4-fold), blood serum (8-fold) and BALF (6-fold) of MCS-free mice as well as in the urinary bladder (5-fold), skeletal muscle (5fold) and BALF (3-fold) of MCS-exposed mice.

\section{Effect of low dose celecoxib on miRNA expression in 10 organs and 3 body fluids of mice, either sham-exposed or MCS-exposed}

The effects of low dose celecoxib (20 mg/kg diet) were evaluated in the lung, blood serum, and urines of female mice, either smoke-free or MCS-exposed. In all body compartments, the number of miRNAs modulated by 
celecoxib when administered at low dose was by far lower than the number observed at high dose, both in the absence and in the presence of MCS exposure. It is of interest that the same pulmonary miRNAs that were modulated by celecoxib at low dose (identified with an asterisk in Table 5) were also modulated by celecoxib at high dose, thus being identifiable as sensitive and specific biomarkers of celecoxib effect in lung.

In particular, in lung low dose celecoxib modulated the expression of miR-296 (2.4-fold upregulation) and miR-551b (2.2-fold upregulation) as compared to sham, and it downregulated the expression of miR185 (2.8fold downregulation) as compared to MCS-exposed mice. Accordingly, the number of miRNAs modulated by celecoxib at low dose was only 3 as compared to the 14 miRNAs modulated in lung by celecoxib at high dose (see Table 5). In blood serum, low dose celecoxib modulated the expressions of miR30c-5p (2.9-fold downregulation), as compared to sham, and of miR-185 (2.1-fold downregulation) as compared to MCS-exposed mice. Accordingly, the number of miRNAs modulated by celecoxib at low dose was only 2 as compared to the 11 miRNAs modulated by celecoxib at high dose in the blood (see Table 5). In urine, low dose celecoxib modulated the expression of both miR-290 (2.4-fold downregulation) and miR-1945b (2.4-fold downregulation) as compared to sham. Accordingly, the number of miRNAs modulated by celecoxib at low dose in urine was 2 as compared to 3 miRNAs modulated by celecoxib at high dose (see Table 5).

\section{DISCUSSION}

The present article reports the results of three consecutive studies evaluating the effects of treatment with celecoxib and/or exposure to MCS on genomic and miRNA alterations in the lung and blood serum of newborn Swiss H mice (Study 1), occurrence of bulky DNA adducts in the lung, liver, and heart of newborn ICR (CD-1) mice (Study 2), and alterations of miRNA expression profiles in 10 organs and 3 body fluids of young Swiss ICR (CD-1) mice (Study 3). The overall results obtained demonstrate that this NSAID causes genomic and epigenetic alterations in the lung, heart, and other body compartments of MCSfree mice but, on the other hand, its administration exerts protective effects towards imbalances of the same endpoints in smoking mice.

In the interpretation of the results obtained it should be kept in mind that in Study 3 administration of celecoxib started short before beginning of exposure to MCS, whereas in both Study 1 and Study 2 administration of celecoxib started about one month after beginning of exposure to MCS, as soon as the mice became able to eat autonomously. In Study 1 and Study 2 the mice were treated with celecoxib during the 6 weeks following weanling, i.e., from the 5 th to the 10 th week of life. This period partially overlaps with adolescence [23], leading to sexual maturity and early adulthood. Note that, besides being prescribed in adults, celecoxib can be also used to treat juvenile rheumatoid arthritis in children 2 years and older (https://www.accessdata.fda.gov/drugsatfda_docs/la bel/2011/020998s033,021156s003lbl.pdf).

The mice were exposed whole-body to MCS, whereas in humans MCS is inhaled as an undiluted complex mixture directly into the respiratory tract and therefore its doses are probably even higher than those inhaled by mice. The celecoxib dose used $(1,600 \mathrm{mg} / \mathrm{kg}$ diet) was selected based on the results of a preliminary subchronic toxicity study in which administration of the drug to smoke-free, post-weanling mice for 6 weeks did not cause any body weight or behavioral alterations [18]. Although this dose is rather high, it is similar or even lower than those used in most animal studies available in the literature. Furthermore, it is of the same order of magnitude as the pharmacological doses used in humans. In fact, it has been reported that $1,000 \mathrm{mg} / \mathrm{kg}$ diet of celecoxib results in a plasma concentration of $1.6 \mu \mathrm{g}$ / $\mathrm{ml}$ in mice, which approximates the reported therapeutic plasma concentration of celecoxib in humans [6]. In this comparison, it should be taken in mind that, while celecoxib in humans is administered once or twice per day, mice eat continuously depending on their metabolic needs, which results in a highly fractionated drug intake with the diet.

Exposure of both Swiss H mice and ICR (CD-1) mice to MCS during the first 10 weeks of life resulted in the massive formation of bulky DNA adducts to lung DNA, which was documented by autoradiographic DRZs. These patterns are typical of exposures to complex mixtures such as CS [24]. Later on, exposure of $\mathrm{H}$ mice to MCS during the first 4 months of life caused a systemic genomic damage, which was demonstrated by a significant increase of micronuclei in the erythrocytes. The contribution of oxidative mechanisms to the formation of MCS-related nucleotide alterations was supported by the parallel sharp increase of 8-oxo-dGuo in mouse lung in Swiss H mice. Likewise, high levels of DNA adducts were detected in the heart of MCS-exposed ICR (CD-1) mice, whereas just a marginal increase was appreciable in their liver. These findings are in agreement with the results of previous studies in adult rats exposed to ECS. The main difference between lung and heart is that DNA adduct levels rapidly decline in the lung upon discontinuation of exposure to CS, whereas they are more persistent in the heart, presumably due to a lower efficiency of DNA repair mechanisms [25]. Cell proliferation is another distinctive mechanism between lung and heart. In fact, the cells of the bronchoalveolar tract are characterized by a high proliferation rate, while cardiomyocytes are perennial cells after birth. Accordingly, while the presence of nucleotide alterations in the lung are predictive of a possible evolution towards cancer, no such evolution can be envisaged in the heart, because cell proliferation is a condicio sine qua non 
for the formation of neoplastic diseases. Rather, nucleotide alterations in cardiomyocytes are possibly related to an evolution towards genuinely degenerative heart diseases $[26,27]$.

A rather unexpected finding was that treatment with celecoxib caused the evident formation of DNA adducts in both mouse lungs and heart. In fact, the oral administration of this NSAID after weanling, from the 5th to the 10th week of life, resulted in the formation of autoradiographic spots, which was not accompanied by any oxidative DNA damage. Formation of celecoxib-specific DNA adducts in the lung was first demonstrated in the study using Swiss $\mathrm{H}$ mice (Study 1). In order to validate this finding, we carried out a further ad hoc study (Study 2), in which we treated mice belonging to another strain [ICR (CD-1)] according to the same protocol. The results confirmed that administration of celecoxib to smoke-free mice causes the formation of DNA adducts in the lung and, additionally, in the heart, whereas this kind of lesion was negligible in the liver. These findings are presumably related to the distinctive pharmacokinetic and metabolism of this NSAID in different organs. It is known that, in various animal species, the methyl group of celecoxib is first oxidized to a hydroxymethyl metabolite, followed by additional oxidation of the hydroxymethyl group to a carboxylic acid metabolite [28]. Using human liver microsomes, methyl hydroxylation of celecoxib was found to be primarily catalyzed by CYP2C9 [29], which is involved in the metabolism of endogenous compounds, drugs, and procarcinogens, also including CS components [30].

The results of our studies agree with the results of another study [31], in which the levels of adducts formed by ${ }^{3} \mathrm{H}-\mathrm{B}(a) \mathrm{P}$ [benzo $(a)$ pyrene] in CS-exposed mice were significantly decreased by oral celecoxib in the liver but were significantly increased in the lung. These data are not coincident with ours, because we evaluated all smoke-related DNA adducts and not only those formed by BPDE [benzo $(a)$ pyrene diolepoxide]. In addition, as we will discuss below, we found that celecoxib decreases MCS-related DNA adduct levels. Nevertheless, these findings suggest a tissue specificity in the ability of celecoxib to form DNA adducts. Koul et al. [31] ascribed these differential patterns to the fact that celecoxib administration results in a significant decrease of GST (glutathione $S$-transferase) activity in the lung but not in the liver, which may justify an impaired detoxification of the celecoxib reactive metabolite(s) in the lung.

On the other hand, celecoxib inhibited the formation of MCS-related DNA adducts in the heart and, even more efficiently, in the lung. This demonstrates that celecoxib exerts protective effects towards induction of nucleotide alterations in MCS-exposed mice and that the overall protective effects resulting from co-treatment of mice with MCS and celecoxib are prevalent as compared with the DNA damage produced by this COX-2 inhibitor when given to MCS-free mice. These results are consistent with the finding that celecoxib is able to exert protective effects in Swiss $\mathrm{H}$ mice exposed to MCS. In particular, besides attenuating preneoplastic alterations in the urinary tract, celecoxib decreased the multiplicity of MCS-induced lung adenomas. Moreover, the yield of lung malignant tumors was lower in MCS-exposed mice treated with celecoxib compared to those MCS-exposed mice that did not receive the chemopreventive regimen. However, at the same dose used in the present study, celecoxib became toxic to MCS-exposed mice and some signs of hepatotoxicity were detected in MCS-exposed mice treated with celecoxib [18]. In humans, a case-control study showed that use of selective COX-2 inhibitors, among which celecoxib, reduced the lung cancer risk [12], and a trial of celecoxib in former smokers decreased the bronchial Ki-67 labeling index and reduced lung nodules on computed tomography [13]. In human lung carcinoma H1299 cells, celecoxib suppressed several molecular alterations induced by a CS condensate [32].

In addition to genomic damage, exposure of mice to MCS resulted in multiorgan epigenetic alterations, in the form of dysregulation of miRNA profiles. MCS induced a prevalent downregulation of miRNAs in the lung, in agreement with previous studies in rats $[33,34]$ and mice [35-43]. The same conclusion was drawn in studies evaluating miRNA expression in the bronchial epithelium from humans who smoke [44]. The results relative to dysregulation of miRNA expression in the lung and blood of newborn Swiss H mice (Study 1) and in 10 organs and 3 body fluids of young Swiss ICR (CD-1) mice (Study 3) have been separately reported and commented in previous studies in which microarray data had been validated by qPCR analyses [22, 42].

Here we will discuss the results relative to dysregulation of miRNA expression following administration of celecoxib either to smoke-free mice or to MCS-exposed mice. In Swiss H mice treated with celecoxib after weanling (Study 1), the effects of the drug in the lung was mainly in the sense of upregulation. The most intensely upregulated miRNAs by celecoxib included miR-106b, which is involved in cell adhesion, tumor necrosis factor (TNF) activation, and stress response, and miR-582 and miR-328, both of which are involved in cell proliferation and apoptosis. Two of the miRNAs upregulated by celecoxib in mouse lung (miR-181, miR-208a) were also upregulated in the blood serum, but most miRNAs whose concentrations were increased in the blood were unaffected in the lung. It is conceivable that celecoxib-related miRNAs in blood serum reflect molecular changes induced by this drug not only in lung but also in other organs bearing relevance for the pharmacodynamic activity of this drug, such as liver and heart. In fact, besides miR-208a, which has been related to the occurrence of heart damage (see below), 7 of the 18 blood miRNAs altered by celecoxib are liver specific. Similar conclusions were drawn by evaluating miRNA dysregulation by celecoxib in 10 organs 
and 3 body fluids of Swiss ICR (CD-1) mice (Study 3). In fact, the drug induced the release of miRNAs into the blood mainly from kidney, stomach, and liver. These organs are established targets of this COX-2 inhibitor for both protective and adverse effects (gastritis and nephrotoxicity). A similar situation occurred in the BALF, although the number of miRNAs altered by celecoxib was by far lower than in blood. These finding indicate that celecoxib, administered with the diet, does not preferentially target the lung, this organ being only a secondary target as compared to kidney, stomach, liver, and spleen. In contrast, it is likely that the miRNAs released into BALF reflect plasma ultrafiltration processes contributing to the production of bronchial mucus. Kidney, stomach and bladder were the main contributors of miRNAs modulated by celecoxib treatment in urine.

The comparison of miRNA profiles in mice treated with celecoxib, either exposed or unexposed to MCS, was investigated in order to assess which biological fluid better predicts the preventive effects of this drug against miRNA alterations induced by MCS. In the blood, the great contribution of kidney and bladder is consistent with the fact that these organs are targets for both celecoxib and MCS. The spleen contribution, being this organ widely populated by immune-competent cells, reflects the specific anti-inflammatory activity of celecoxib against MCSinduced inflammation. The analysis of BALF further supported the fact that lung is just a secondary target for celecoxib as compared to other organs. In urines, the number of modulated miRNAs was low.

Among other miRNAs modulated by celecoxib, it is of interest that miR-21 was downregulated both in the stomach and in the blood of ICR (CD-1) mice treated with this NSAID. This miRNA had been found to be upregulated in cultured human gastric adenocarcinoma cells treated with nicotine, which also stimulated $\mathrm{COX}-2 /$ prostaglandin $\mathrm{E}$ (PGE) signaling via modulation of NF- $\kappa \mathrm{B}$ activity [45]. In the present study, the transcription factor $\mathrm{NF}-\kappa \mathrm{B}$ was targeted by a number of miRNAs in organs and body fluids of celecoxib-treated mice, either smoke-free and/or MCS-exposed. In particular, celecoxib-modulated miRNAs that target NF- $\kappa$ B included members of the miR30 family, such as miR-30a (lung), miR-30b (liver, heart, kidney, colon, heart, spleen, urinary bladder), miR-30c1-3p (stomach, urinary bladder), miR-30c-2-3p (lung, kidney, spleen, urinary bladder), miR-30c-5p (liver, heart, kidney, spleen, stomach, skeletal muscle, blood, BALF), miR-30d (lung, skeletal muscle), and miR-30e (lung, liver, kidney, urinary bladder, skeletal muscle, blood); members of the miR-181 family, including miR-181b (lung, urinary bladder, stomach, BALF), miR-181c-3p (lung, stomach), miR-181c-5p (urinary bladder, skeletal muscle), and miR181d (lung, stomach, urinary bladder); and miR-185-3p (kidney, stomach, spleen, skeletal muscle).

By comparing the data obtained in celecoxibtreated mice, either unexposed or exposed to MCS, it is noteworthy that 10 miRNAs (miR-106a, miR-290, miR381, miR-471, miR-615, miR-758, miR-1247, miR-3070, miR-3085, and miR-3109) were upregulated by celecoxib in the lung of both sham-exposed and MCS-exposed newborn Swiss $\mathrm{H}$ mice, while no miRNA was modulated by celecoxib in the lung of both sham-exposed and MCSexposed adult ICR (CD-1) mice. Although we cannot rule out possible interstrain differences, these results show a sharp difference in the epigenetic response to this NSAID when administered for 6 weeks either to post-weanling mice exposed to MCS since birth or to adult mice in which treatment with celecoxib started shortly before the first exposure to MCS. Such an age-related difference was also confirmed by the finding that 6 miRNAs (miR21/21a, miR-185, miR-335, miR-361, miR-695, and miR-1964) were upregulated by celecoxib in the blood serum of MCSfree Swiss $\mathrm{H}$ mice, while all of them were downregulated in the blood serum of young adult ICR (CD-1) mice. Four miRNAs (miR-181-b/c, miR-471, miR-511/511b, and miR-1247) were upregulated by celecoxib in the lung of both MCS-free newborn Swiss $\mathrm{H}$ mice and young adult ICR (CD-1) mice. Two miRNAs (miR-185, and miR-335) were downregulated by celecoxib in the blood serum of both sham-exposed and MCS-exposed ICR (CD-1) mice. The same two miRNAs were downregulated by celecoxib in both lung and blood serum of MCS-exposed ICR (CD1) mice. It is noteworthy that, in MCS-exposed mice, miR-185 was modulated both in lung and blood serum at both low and high celecoxib doses. Therefore, this miRNA represents a blood biomarker that reflects the protective effect exerted by this COX-2 inhibitor in the lung.

There are concerns regarding the cardiotoxicity of several agents used both in cancer treatment and in cancer prevention [46], among which the case of celecoxib is paradigmatic $[9,10]$. In addition to the previously discussed formation of bulky DNA adducts in the heart of mice treated with celecoxib, it was of interest to evaluate modulation by this drug of those miRNAs that are known to target the heart. Of the miRNAs analyzed in the present study, miR-308 was upregulated by celecoxib in the blood serum of MCS-free neonatal Swiss $\mathrm{H}$ mice, and miR208 was upregulated in both lung and blood serum of the same mice. In adult ICR (CD-1) mice, miR-30c-5p was downregulated in several organs, among which heart, and in the blood serum of MCS-free mice. Within the same miRNA family, miR-30b was downregulated in the heart of both MCS-free and MCS-exposed mice.

Of the above mentioned miRNAs, miR-30 plays a role in myocardial matrix remodeling [47] and contributes to endoplasmic reticulum stress in cardiac muscle and vascular smooth muscle cells [48]. miR-208 has been included in the list of muscle-specific miRNAs, called myomiRs, and has extensively been investigated both in cardiomyocyte development [49] and heart injury [50]. As inferred from studies in rats, this miRNA has been proposed as a plasmatic biomarker of myocardial 
injury [51] and other cardiovascular diseases [52]. In addition, miR-208 has been suggested to be a potent therapeutic target for the modulation of cardiac function and remodeling during heart disease progression [53]. From a mechanistic point of view, it has been proposed that downregulation of miR-208 contributes to reactive oxygen species (ROS) production in mouse cardiomyocytes and enhances apoptosis of these cells mainly by targeting p21 [54]. The same considerations may hold true for miR-328, the other miRNA that we found to be increased in the blood serum of celecoxibtreated Swiss H mice. In fact, studies in humans showed that circulating miR-328 could be a potential indicator for heart injury, and the levels of this miRNA are associated with increased risk of mortality or development of acute myocardial infarction [55], cardiac hypertrophy [56], and atrial fibrillation [57].

Our finding that both miR-208 and miR-328 are upregulated in mice treated with celecoxib early in life is new and may contribute to understand the cardiovascular effects produced by this selective COX-2 inhibitor. Accordingly, it may be assumed that maintenance of these miRNAs at an appropriate level in the blood of celecoxibtreated individuals may be taken as a safety indicator in order to avoid possible adverse effects of this drug on the cardiovascular system.

In conclusion, the results of the three studies reported in the present article show that celecoxib is able to attenuate the DNA alterations produced by MCS in mouse lung in terms of bulky DNA adducts and oxidative DNA damage. Moreover, celecoxib counteracted the MCS-related dysregulation of several miRNAs in a variety of organs and body fluids thereby suggesting that this NSAID has pleiomorphic properties. Such a conclusion is in agreement with the hypothesis that NSAIDs may reduce the "inflammogenesis of cancer" not only by interfering with the arachidonic acid cascade but also through multiple mechanisms $[2,58,59]$. CS induces inflammation also by blocking miRNA maturation at the DICER level, thus causing accumulation of miRNA precursors in cytoplasm that trigger TLR (toll-like receptor) activation $[60,61]$. The findings of the present studies evaluating genomic and epigenetic biomarkers are consistent with the results of a parallel medium-term bioassay in Swiss $\mathrm{H}$ mice in which celecoxib attenuated the MCS-induced alterations of inflammatory nature, the yield of lung adenomas, and progression to cancer in the lung [18].

On the other hand, administration of celecoxib to non-smoking mice resulted in evident molecular alterations. These included the selective formation of bulky DNA adducts in both lung and heart and the dysregulation of a number of miRNAs in various organs, also including those miRNAs that are heart-specific and have been involved in cardiovascular diseases, which may bear relevance in the pathogenesis of the cardiovascular adverse effects of this drug.

\section{MATERIALS AND METHODS}

\section{General design of the studies}

In all 3 studies the mice were divided into the following 4 groups: (a) mice kept in filtered air (sham); (b) mice treated with celecoxib; (c) mice exposed to MCS; and $(d)$ mice exposed to MCS and treated with celecoxib. Study 1 evaluated the levels of bulky DNA adducts and the intensity of oxidative DNA damage in lung, the frequency of micronucleated normochromatic erythrocytes (MN NCE) in the blood, and the expression of miRNAs in both lung and blood of Swiss $\mathrm{H}$ mice as related to exposure to MCS for 10 weeks, starting at birth, and administration of celecoxib after weanling (about 4 weeks) until the 10th week of life. Ten mice per group (5 males and 5 females) were used. Study 2 evaluated the levels of bulky DNA adducts in the lung, liver, and heart of Swiss ICR (CD1) mice as related to exposure to MCS for 10 weeks, starting at birth, and administration of celecoxib after weanling (about 4 weeks) until the 10th week of life. Twenty mice per group (10 males and 10 females) were used. Study 3 evaluated the expression of miRNAs in 10 organs, including lung, liver, heart, kidney, spleen, urinary bladder, skeletal muscle (left gastrocnemius), colon, stomach, and brain, and 3 body fluids, including blood serum, bronchoalveolar lavage fluid (BALF), and urines, of two-month old Swiss ICR (CD-1) mice, as related to exposure to MCS for 8 weeks and administration of celecoxib for the same period, starting 3 days before exposure to MCS. Each group was composed of 10 female mice.

\section{Mice}

Strain H neonatal mice, used in Study 1, were born at the Animal Laboratory of the National Center of Oncology (Sofia, Bulgaria). The mice were housed in Makrolon $^{\mathrm{TM}}$ cages on sawdust bedding and maintained on standard rodent chow (Kostinbrod, Bulgaria) and allowed drinking water ad libitum. Swiss ICR (CD-1) mice, either neonatal (Study 2) or two- month old (Study 3), were purchased from Harlan Laboratories (San Pietro al Natisone, Udine, Italy). The mice were housed in Makrolon ${ }^{\mathrm{TM}}$ cages on sawdust bedding and maintained on standard rodent chow (Teklad 9607, Harlan Laboratories) and tap water ad libitum. The animal room temperature was $23 \pm 2^{\circ} \mathrm{C}$, with a relative humidity of $55 \%$ and a $12 \mathrm{~h}$ day-night cycle. Housing and treatments of mice were in accordance with NIH, European (2010/63 UE Directive), and institutional guidelines. The issuance of the NIH 
Office of Laboratory Animal Welfare (OLAW) with the University of Genoa bears the identification number A5899-01 and is effective until February 28, 2021. The Institutional Animal Care and Use Committee (IACUC) protocol was approved by the Fox Chase Cancer Center Committee on April 13, 2015.

\section{Exposure to MCS}

A whole-body exposure of the mice to MCS was achieved as previously described [20, 22], by using 3R4F Kentucky reference cigarettes (College of Agriculture, The Reference Cigarette Program, University of Kentucky, Lexington, KY), having a declared content of $9.4 \mathrm{mg}$ tar, $0.73 \mathrm{mg}$ nicotine, and delivering $12 \mathrm{mg}$ of $\mathrm{CO}$ each when burned. MCS was delivered to the exposure chambers by drawing 15 consecutive puffs, each of $60 \mathrm{ml}$ and lasting $6 \mathrm{~s}$. Each daily session involved 6 consecutive exposures, lasting $10 \mathrm{~min}$ each, with $1 \mathrm{~min}$ intervals during which a total air change was made. Exposure started either within $12 \mathrm{~h}$ after birth (Study 1 and Study 2) or at the age of 2 months (Study 3) and continued daily for 8-10 weeks. The average total particulate matter (TPM) concentrations in the exposure chambers were $689 \mathrm{mg} /$ $\mathrm{m}^{3}$ in Study 1, $737 \mathrm{mg} / \mathrm{m}^{3}$ in Study 2, and $784 \mathrm{mg} / \mathrm{m}^{3}$ in Study 3.

\section{Administration of celecoxib}

Celecoxib was supplied by the US National Cancer Institute (NCI) via MRIGlobal (Kansas City, MO). Based on a preliminary subchronic toxicity study in Swiss $\mathrm{H}$ mice [18], it was decided to incorporate celecoxib in the mouse diet at the dose of $1,600 \mathrm{~g} / \mathrm{Kg}$ diet, which corresponded to the $80 \%$ of the maximum dose that did not produce any bodyloss or sufferance or alterations in the behavior of smoke-free mice after 6 weeks of treatment. Moreover, in Study 3 two additional groups of female mice, either smoke-free or MCS-exposed, received low dose celecoxib (20 mg/kg diet).

In Study 1 and Study 2, feeding of the drugcontaining diet started after weanling (about 4 weeks) and continued until the 10th week of life. In Study 3, administration of celecoxib with the diet started 3 days before the first exposure to MCS and continued until the end of the experiment ( 8 weeks).

\section{Euthanasia of mice and collection of organs and body fluids}

At the end of each experiment, the mice were euthanized. Each mouse was transferred into a separate chamber and isolated from the other mice. The 2013 American Veterinary Medical Association (AVMA) guidelines on euthanasia were followed using slow introduction of $\mathrm{CO}_{2}$ asphyxiation, and death was confirmed by absence of respiration and/or heartbeat.
The urine was collected for $8 \mathrm{~h}$ and pooled from the mice belonging to each experimental group in Study 3 by using metabolic cages during the day preceding euthanasia of mice. Immediately after sacrifice, a bronchoalveolar lavage (BAL) was performed and used for preparing BALF, and the blood was collected and used for preparing serum. BALF and blood serum were pooled within each experimental group. The organs reported in the general design of the studies were collected, as previously described [22]. Immediately after collection, each organ or fluid was immersed in RNAlater and kept at $-80^{\circ} \mathrm{C}$ for miRNA analysis. Portions of the organs used in Study 1 and Study 2 were stored at $-80^{\circ} \mathrm{C}$ for evaluating DNA damage. Moreover, in order to evaluate the frequency of MN NCE, the blood was collected from the lateral tail vein of 40 neonatal Swiss $H$ mice (20 males and 20 females), used in parallel experiments [18], which were exposed to MCS and/or treated with celecoxib until the 4th month of life.

\section{Extraction and ${ }^{32} \mathrm{P}$ postlabeling analysis of lung DNA}

DNA was extracted from tissue specimens (50 $\mathrm{mg}$ ) collected individually from the lungs of 40 Swiss $\mathrm{H}$ mice used in Study 1 and from lungs, heart and liver of 80 ICR (CD-1) mice used in Study 2, as previously described [23]. Bulky DNA adducts, after butanol enrichment, and 8-hydroxy-2'-deoxyguanosine (8-oxodGuo) were measured by ${ }^{32} \mathrm{P}$ postlabeling as previously described [62].

\section{Modulation of the systemic MCS genotoxicity}

At 4 months of age, immediately after discontinuing exposure to MCS, peripheral blood was collected from the tail lateral vein and smeared onto slides ( 2 slides/mouse) from 20 mice (10 males and 10 females) per each one of the 4 experimental groups. After staining with MayGrünwald-Giemsa, the frequency of MN NCE was scored by analyzing microscopically 50,000 NCE/mouse.

\section{Extraction of RNA and analysis of miRNA expression in mouse organs and body fluids}

RNA was extracted from mouse organs (miRNeasy, Qiagen, Hilden, Germany) and body fluids (Exiqon's miRCURYTM RNA Isolation Kit - Biofluids (Exiqon, Vedbaek, Denmark) according to the manufacturers' instructions. The quality of the RNA extracted was evaluated by spectrophotometric analyses using a fiber optic spectrophotometer (Nanodrop ND-1000).

For evaluating the expression of pulmonary miRNAs we used the 7th generation miRCURY LNA ${ }^{\mathrm{TM}}$ microRNA Array (Exiqon), which contains 3,100 capture probes covering human, mouse and rat miRNAs. In particular, this array covers 1,135 mouse miRNAs, i.e. 
the $88.6 \%$ of the 1,281 mouse miRNAs listed in miRBase 19. Microarray analyses were carried out as previously described [22].

Microarray data have been recorded in the GEO database (GEO accession No. requested).

\section{Statistical analysis}

Treatment-related differences in body weights, in the frequency of MN NCE, and in the levels of pulmonary DNA adducts and 8-oxo-dGuo, all of them expressed as means $\pm \mathrm{SE}$ within each group of mice, were evaluated for statistical significance by ANOVA followed by Student's $t$ test for unpaired data. miRNA microarray data, after local background subtraction, log transformation, and normalization were analyzed by GeneSpring software (Agilent, Santa Clara, CA), and expression data were median centered by using the GeneSpring normalization option. The statistical significance of the differences between experimental groups was evaluated by means of the GeneSpring ANOVA applied by using Bonferroni multiple testing correction. As inferred from volcano-plot analysis, differences between sets of data were taken as significant when they were both statistically significant $(P<0.05)$ and showed at least a two-fold variation. The overall variability of microarray data, as related to treatments, was evaluated by scatter-plot analysis (SPA), hierarchical cluster analysis (HCA), and principal component analysis (PCA).

\section{CONFLICTS OF INTEREST}

The authors have declared no conflicts of interest.

\section{FUNDING}

This study was supported by the U.S. National Cancer Institute (Contracts \#HHSN-261200433000C and \#HHSN261201200015I) and by the Italian Association for Cancer Research (AIRC, grant No. IG-20699).

\section{REFERENCES}

1. Smith CJ, Perfetti TA, King JA. Perspectives on pulmonary inflammation and lung cancer risk in cigarette smokers. Inhal Toxicol. 2006; 18:667-77. https://doi. org/10.1080/08958370600742821.

2. Aggarwal BB, Shishodia S, Sandur SK, Pandey MK, Sethi G. Inflammation and cancer: how hot is the link? Biochem Pharmacol. 2006; 72:1605-21. https://doi.org/10.1016/j. bcp.2006.06.029.

3. Grivennikov SI, Greten FR, Karin M. Immunity, inflammation, and cancer. Cell. 2010; 140:883-99. https:// doi.org/10.1016/j.cell.2010.01.025.
4. Takahashi H, Ogata H, Nishigaki R, Broide DH, Karin M. Tobacco smoke promotes lung tumorigenesis by triggering IKKbeta- and JNK1-dependent inflammation. Cancer Cell. 2010; 17:89-97. https://doi.org/10.1016/j.ccr.2009.12.008.

5. Mazhar D, Gillmore R, Waxman J. COX and cancer. QJM. 2005; 98:711-18. https://doi.org/10.1093/qjmed/hci119.

6. Davies NM, McLachlan AJ, Day RO, Williams KM. Clinical pharmacokinetics and pharmacodynamics of celecoxib: a selective cyclo-oxygenase-2 inhibitor. Clin Pharmacokinet. 2000; 38:225-42. https://doi. org/10.2165/00003088-200038030-00003.

7. Wolfe F, Anderson J, Burke TA, Arguelles LM, Pettitt D. Gastroprotective therapy and risk of gastrointestinal ulcers: risk reduction by COX-2 therapy. J Rheumatol. 2002; 29:467-73.

8. Deeks JJ, Smith LA, Bradley MD. Efficacy, tolerability, and upper gastrointestinal safety of celecoxib for treatment of osteoarthritis and rheumatoid arthritis: systematic review of randomised controlled trials. BMJ. 2002; 325:619. https:// doi.org/10.1136/bmj.325.7365.619.

9. Bertagnolli MM, Eagle CJ, Zauber AG, Redston M, Breazna A, Kim K, Tang J, Rosenstein RB, Umar A, Bagheri D, Collins NT, Burn J, Chung DC, et al, and Adenoma Prevention with Celecoxib Study Investigators. Five-year efficacy and safety analysis of the Adenoma Prevention with Celecoxib Trial. Cancer Prev Res (Phila). 2009; 2:310 21. https://doi.org/10.1158/1940-6207.CAPR-08-0206.

10. Thompson PA, Ashbeck EL, Roe DJ, Fales L, Buckmeier J, Wang F, Bhattacharyya A, Hsu CH, Chow SH, Ahnen DJ, Boland CR, Heigh RI, Fay DE, et al. Celecoxib for the prevention of colorectal adenomas: results of a suspended randomized controlled trial. J Natl Cancer Inst. 2016; 108:108. https://doi.org/10.1093/jnci/djw151.

11. Miao XP, Li JS, Ouyang Q, Hu RW, Zhang Y, Li HY. Tolerability of selective cyclooxygenase 2 inhibitors used for the treatment of rheumatological manifestations of inflammatory bowel disease. Cochrane Database Syst Rev. 2014; 23:CD007744.

12. Harris RE, Beebe-Donk J, Alshafie GA. Reduced risk of human lung cancer by selective cyclooxygenase 2 (COX2) blockade: results of a case control study. Int J Biol Sci. 2007; 3:328-34. https://doi.org/10.7150/ijbs.3.328.

13. Mao JT, Roth MD, Fishbein MC, Aberle DR, Zhang ZF, Rao JY, Tashkin DP, Goodglick L, Holmes EC, Cameron RB, Dubinett SM, Elashoff R, Szabo E, Elashoff D. Lung cancer chemoprevention with celecoxib in former smokers. Cancer Prev Res (Phila). 2011; 4:984-93. https://doi. org/10.1158/1940-6207.CAPR-11-0078.

14. Koul A, Arora N. Celecoxib mitigates cigarette smoke induced oxidative stress in mice. Indian J Biochem Biophys. 2010; 47:285-91.

15. Fischer SM, Hawk ET, Lubet RA. Coxibs and other nonsteroidal anti-inflammatory drugs in animal models 
of cancer chemoprevention. Cancer Prev Res (Phila). 2011; 4:1728-35. https://doi.org/10.1158/1940-6207. CAPR-11-0166.

16. Kisley LR, Barrett BS, Dwyer-Nield LD, Bauer AK, Thompson DC, Malkinson AM. Celecoxib reduces pulmonary inflammation but not lung tumorigenesis in mice. Carcinogenesis. 2002; 23:1653-60. https://doi. org/10.1093/carcin/23.10.1653.

17. Sereno J, Parada B, Reis F, Cunha FX, Teixeira-Lemos E, Garrido P, Pinto R, Rocha-Pereira P, Neto P, Ruivo J, Rodrigues-Santos P, Nunes S, Mota A, et al. Preventive but not curative efficacy of celecoxib on bladder carcinogenesis in a rat model. Mediators Inflamm. 2010; 2010:380937. https://doi.org/10.1155/2010/380937.

18. Balansky R, Ganchev G, Iltcheva M, Nikolov M, La Maestra S, Micale RT, D’Agostini F, Steele VE, De Flora S. Modulation by licofelone and celecoxib of experimentally induced cancer and preneoplastic lesions in mice exposed to cigarette smoke. Curr Cancer Drug Targets. 2015; 15:18895. https://doi.org/10.2174/1568009615666150216170008.

19. Reilly TP, Brady JN, Marchick MR, Bourdi M, George JW, Radonovich MF, Pise-Masison CA, Pohl LR. A protective role for cyclooxygenase-2 in drug-induced liver injury in mice. Chem Res Toxicol. 2001; 14:1620-28. https://doi. org/10.1021/tx0155505.

20. Balansky R, Ganchev G, Iltcheva M, Steele VE, D’Agostini F, De Flora S. Potent carcinogenicity of cigarette smoke in mice exposed early in life. Carcinogenesis. 2007; 28:223643. https://doi.org/10.1093/carcin/bgm122.

21. De Flora S, Ganchev G, Iltcheva M, La Maestra S, Micale RT, Steele VE, Balansky R. Pharmacological modulation of lung carcinogenesis in smokers: preclinical and clinical evidence. Trends Pharmacol Sci. 2016; 37:120-42. https:// doi.org/10.1016/j.tips.2015.11.003.

22. Izzotti A, Longobardi M, La Maestra S, Micale RT, Pulliero A, Camoirano A, Geretto M, D’Agostini F, Balansky R, Miller MS, Steele VE, De Flora S. Release of microRNAs into body fluids from ten organs of mice exposed to cigarette smoke. Theranostics. 2018; 8:2147-60. https:// doi.org/10.7150/thno. 22726 .

23. Adriani W, Granstrem O, Macri S, Izykenova G, Dambinova S, Laviola G. Behavioral and neurochemical vulnerability during adolescence in mice: studies with nicotine. Neuropsychopharmacology. 2004; 29:869-78. https://doi.org/10.1038/sj.npp.1300366.

24. De Flora S, Izzotti A, D’Agostini F, Bennicelli C, You M, Lubet RA, Balansky RM. Induction and modulation of lung tumors: genomic and transcriptional alterations in cigarette smoke-exposed mice. Exp Lung Res. 2005; 31:19-35. https://doi.org/10.1080/01902140490494986.

25. Izzotti A, Bagnasco M, D’Agostini F, Cartiglia C, Lubet RA, Kelloff GJ, De Flora S. Formation and persistence of nucleotide alterations in rats exposed whole-body to environmental cigarette smoke. Carcinogenesis. 1999; 20:1499-505. https://doi.org/10.1093/carcin/20.8.1499.
26. De Flora S, Izzotti A, Randerath K, Randerath E, Bartsch H, Nair J, Balansky R, van Schooten F, Degan P, Fronza G, Walsh D, Lewtas J. DNA adducts and chronic degenerative disease. Pathogenetic relevance and implications in preventive medicine. Mutat Res. 1996; 366:197-238. https://doi.org/10.1016/S0165-1110(96)00043-7.

27. De Flora S, Izzotti A. Modulation of genomic and postgenomic alterations in noncancer diseases and critical periods of life. Mutat Res. 2009; 667:15-26. https://doi. org/10.1016/j.mrfmmm.2008.09.010.

28. Paulson SK, Zhang JY, Breau AP, Hribar JD, Liu NW, Jessen SM, Lawal YM, Cogburn JN, Gresk CJ, Markos CS, Maziasz TJ, Schoenhard GL, Burton EG. Pharmacokinetics, tissue distribution, metabolism, and excretion of celecoxib in rats. Drug Metab Dispos. 2000; 28:514-21.

29. Tang C, Shou M, Mei Q, Rushmore TH, Rodrigues AD. Major role of human liver microsomal cytochrome P450 2C9 (CYP2C9) in the oxidative metabolism of celecoxib, a novel cyclooxygenase-II inhibitor. J Pharmacol Exp Ther. 2000; 293:453-59.

30. Barry EL, Poole EM, Baron JA, Makar KW, Mott LA, Sandler RS, Ahnen DJ, Bresalier RS, McKeown-Eyssen GE, Ulrich CM. CYP2C9 variants increase risk of colorectal adenoma recurrence and modify associations with smoking but not aspirin treatment. Cancer Causes Control. 2013; 24:47-54. https://doi.org/10.1007/s10552-012-0088-6.

31. Koul A, Tanwar L, Arora N. Celecoxib administration exhibits tissue specific effect on 3H-benzo(a)pyrene-DNA adduct formation in cigarette smoke inhaling mice. Indian $\mathrm{J}$ Exp Biol. 2009; 47:83-90.

32. Shishodia S, Aggarwal BB. Cyclooxygenase (COX)-2 inhibitor celecoxib abrogates activation of cigarette smokeinduced nuclear factor (NF)-kappaB by suppressing activation of IkappaBalpha kinase in human non-small cell lung carcinoma: correlation with suppression of cyclin D1, COX-2, and matrix metalloproteinase-9. Cancer Res. 2004; 64:5004-12. https://doi.org/10.1158/0008-5472. CAN-04-0206.

33. Izzotti A, Calin GA, Arrigo P, Steele VE, Croce CM, De Flora S. Downregulation of microRNA expression in the lungs of rats exposed to cigarette smoke. FASEB J. 2009; 23:806-12. https://doi.org/10.1096/fj.08-121384.

34. Izzotti A, Calin GA, Steele VE, Cartiglia C, Longobardi M, Croce CM, De Flora S. Chemoprevention of cigarette smoke-induced alterations of MicroRNA expression in rat lungs. Cancer Prev Res (Phila). 2010; 3:62-72. https://doi. org/10.1158/1940-6207.CAPR-09-0202.

35. Izzotti A, Calin GA, Steele VE, Croce CM, De Flora S. Relationships of microRNA expression in mouse lung with age and exposure to cigarette smoke and light. FASEB J. 2009; 23:3243-50. https://doi.org/10.1096/fj.09-135251.

36. Izzotti A, Larghero P, Cartiglia C, Longobardi M, Pfeffer $\mathrm{U}$, Steele VE, De Flora S. Modulation of microRNA expression by budesonide, phenethyl isothiocyanate and 
cigarette smoke in mouse liver and lung. Carcinogenesis. 2010; 31:894-901. https://doi.org/10.1093/carcin/bgq037.

37. Izzotti A, Larghero P, Balansky R, Pfeffer U, Steele VE, De Flora S. Interplay between histopathological alterations, cigarette smoke and chemopreventive agents in defining microRNA profiles in mouse lung. Mutat Res. 2011; 717:17-24. https://doi.org/10.1016/j.mrfmmm.2010.10.003.

38. Izzotti A, Larghero P, Longobardi M, Cartiglia C, Camoirano A, Steele VE, De Flora S. Dose-responsiveness and persistence of microRNA expression alterations induced by cigarette smoke in mouse lung. Mutat Res. 2011; 717:9 16. https://doi.org/10.1016/j.mrfmmm.2010.12.008.

39. De Flora S, Balansky R, D’Agostini F, Cartiglia C, Longobardi M, Steele VE, Izzotti A. Smoke-induced microRNA and related proteome alterations. Modulation by chemopreventive agents. Int J Cancer. 2012; 131:2763-73. https://doi.org/10.1002/ijc.27814.

40. Izzotti A, Balansky R, D'Agostini F, Longobardi M, Cartiglia C, La Maestra S, Micale RT, Camoirano A, Ganchev G, Iltcheva M, Steele VE, De Flora S. Relationships between pulmonary micro-RNA and proteome profiles, systemic cytogenetic damage and lung tumors in cigarette smoke-exposed mice treated with chemopreventive agents. Carcinogenesis. 2013; 34:232229. https://doi.org/10.1093/carcin/bgt178.

41. Izzotti A, Balansky R, D'Agostini F, Longobardi M, Cartiglia C, Micale RT, La Maestra S, Camoirano A, Ganchev G, Iltcheva M, Steele VE, De Flora S. Modulation by metformin of molecular and histopathological alterations in the lung of cigarette smoke-exposed mice. Cancer Med. 2014; 3:719-30. https://doi.org/10.1002/cam4.234.

42. Izzotti A, Balansky R, Ganchev G, Iltcheva M, Longobardi M, Pulliero A, Geretto M, Micale RT, La Maestra S, Miller MS, Steele VE, De Flora S. Blood and lung microRNAs as biomarkers of pulmonary tumorigenesis in cigarette smokeexposed mice. Oncotarget. 2016; 7:84758-74. https://doi. org/10.18632/oncotarget.12475.

43. Izzotti A, Balansky R, Ganchev G, Iltcheva M, Longobardi M, Pulliero A, Camoirano A, D’Agostini F, Geretto M, Micale RT, La Maestra S, Miller MS, Steele VE, De Flora S. Early and late effects of aspirin and naproxen on microRNAs in the lung and blood of mice, either unexposed or exposed to cigarette smoke. Oncotarget. 2017; 8:8571648. https://doi.org/10.18632/oncotarget.20464.

44. Schembri F, Sridhar S, Perdomo C, Gustafson AM, Zhang X, Ergun A, Lu J, Liu G, Zhang X, Bowers J, Vaziri C, Ott K, Sensinger K, et al. MicroRNAs as modulators of smoking-induced gene expression changes in human airway epithelium. Proc Natl Acad Sci U S A. 2009; 106:2319-24. https://doi.org/10.1073/pnas.0806383106.

45. Shin VY, Jin H, Ng EK, Cheng AS, Chong WW, Wong CY, Leung WK, Sung JJ, Chu KM. NF-кB targets miR-16 and miR-21 in gastric cancer: involvement of prostaglandin $\mathrm{E}$ receptors. Carcinogenesis. 2011; 32:240-45. https://doi. org/10.1093/carcin/bgq240.
46. Albini A, Pennesi G, Donatelli F, Cammarota R, De Flora S, Noonan DM. Cardiotoxicity of anticancer drugs: the need for cardio-oncology and cardio-oncological prevention. J Natl Cancer Inst. 2010; 102:14-25. https://doi.org/10.1093/ jnci/djp440.

47. Duisters RF, Tijsen AJ, Schroen B, Leenders JJ, Lentink V, van der Made I, Herias V, van Leeuwen RE, Schellings MW, Barenbrug P, Maessen JG, Heymans S, Pinto YM, Creemers EE. miR-133 and miR-30 regulate connective tissue growth factor: implications for a role of microRNAs in myocardial matrix remodeling. Circ Res. 2009; 104:170-78, 6p, 178. https://doi.org/10.1161/CIRCRESAHA.108.182535.

48. Chen M, Ma G, Yue Y, Wei Y, Li Q, Tong Z, Zhang L, Miao G, Zhang J. Downregulation of the miR-30 family microRNAs contributes to endoplasmic reticulum stress in cardiac muscle and vascular smooth muscle cells. Int J Cardiol. 2014; 173:65-73. https://doi.org/10.1016/j. ijcard.2014.02.007.

49. Malizia AP, Wang DZ. MicroRNAs in cardiomyocyte development. Wiley Interdiscip Rev Syst Biol Med. 2011; 3:183-90. https://doi.org/10.1002/wsbm.111.

50. Kukreja RC, Yin C, Salloum FN. MicroRNAs: new players in cardiac injury and protection. Mol Pharmacol. 2011; 80:558-64. https://doi.org/10.1124/mol.111.073528.

51. Ji X, Takahashi R, Hiura Y, Hirokawa G, Fukushima Y, Iwai N. Plasma miR-208 as a biomarker of myocardial injury. Clin Chem. 2009; 55:1944-1949.

52. Huang Y, Li J. MicroRNA208 family in cardiovascular diseases: therapeutic implication and potential biomarker. $\mathrm{J}$ Physiol Biochem. 2015; 71:479-86. https://doi.org/10.1007/ s13105-015-0409-9.

53. Montgomery RL, Hullinger TG, Semus HM, Dickinson BA, Seto AG, Lynch JM, Stack C, Latimer PA, Olson EN, van Rooij E. Therapeutic inhibition of miR-208a improves cardiac function and survival during heart failure. Circulation. 2011; 124:1537-47. https://doi.org/10.1161/ CIRCULATIONAHA.111.030932.

54. Liu C, Zheng H, Xie L, Zhang J. Decreased miR-208 induced ischemia myocardial and reperfusion injury by targeting p21. Pharmazie. 2016; 71:719-23.

55. He F, Lv P, Zhao X, Wang X, Ma X, Meng W, Meng $\mathrm{X}$, Dong S. Predictive value of circulating miR-328 and miR-134 for acute myocardial infarction. Mol Cell Biochem. 2014; 394:137-44. https://doi.org/10.1007/ s11010-014-2089-0.

56. Li C, Li X, Gao X, Zhang R, Zhang Y, Liang H, Xu C, Du W, Zhang Y, Liu X, Ma N, Xu Z, Wang L, et al. MicroRNA-328 as a regulator of cardiac hypertrophy. Int J Cardiol. 2014; 173:268-76. https://doi.org/10.1016/j. ijcard.2014.02.035.

57. McManus DD, Lin H, Tanriverdi K, Quercio M, Yin X, Larson MG, Ellinor PT, Levy D, Freedman JE, Benjamin EJ. Relations between circulating microRNAs and atrial fibrillation: data from the Framingham Offspring Study. 
Heart Rhythm. 2014; 11:663-69. https://doi.org/10.1016/j. hrthm.2014.01.018.

58. Harris RE. Cyclooxygenase-2 (cox-2) and the inflammogenesis of cancer. Subcell Biochem. 2007; 42:93126. https://doi.org/10.1007/1-4020-5688-5_4.

59. Lee IT, Yang CM. Inflammatory signalings involved in airway and pulmonary diseases. Mediators Inflamm. 2013; 2013:791231. https://doi.org/10.1155/2013/791231.

60. Izzotti A, Pulliero A. The effects of environmental chemical carcinogens on the microRNA machinery. Int J Hyg Environ Health. 2014; 217:601-27. https://doi.org/10.1016/j. ijheh.2014.01.001.
61. Pulliero A, Fazzi E, Cartiglia C, Orcesi S, Balottin U, Uggetti C, La Piana R, Olivieri I, Galli J, Izzotti A. The Aicardi-Goutières syndrome. Molecular and clinical features of RNAse deficiency and microRNA overload. Mutat Res. 2011; 717:99-108. https://doi.org/10.1016/j. mrfmmm.2011.03.018.

62. Izzotti A, Balansky RM, Dagostini F, Bennicelli C, Myers SR, Grubbs CJ, Lubet RA, Kelloff GJ, De Flora S. Modulation of biomarkers by chemopreventive agents in smoke-exposed rats. Cancer Res. 2001; 61:2472-79. 